IZA DP No. 4338

Financial Liberalization and Democracy:

The Role of Reform Reversals

Nauro F. Campos

Fabrizio Coricelli

August 2009 


\title{
Financial Liberalization and Democracy: The Role of Reform Reversals
}

\author{
Nauro F. Campos \\ Brunel University, \\ CEPR and IZA \\ Fabrizio Coricelli \\ University of Paris 1, Paris School of Economics, \\ University of Siena and CEPR
}

\section{Discussion Paper No. 4338 \\ August 2009}

\author{
IZA \\ P.O. Box 7240 \\ 53072 Bonn \\ Germany \\ Phone: +49-228-3894-0 \\ Fax: +49-228-3894-180 \\ E-mail: iza@iza.org
}

Any opinions expressed here are those of the author(s) and not those of IZA. Research published in this series may include views on policy, but the institute itself takes no institutional policy positions.

The Institute for the Study of Labor (IZA) in Bonn is a local and virtual international research center and a place of communication between science, politics and business. IZA is an independent nonprofit organization supported by Deutsche Post Foundation. The center is associated with the University of Bonn and offers a stimulating research environment through its international network, workshops and conferences, data service, project support, research visits and doctoral program. IZA engages in (i) original and internationally competitive research in all fields of labor economics, (ii) development of policy concepts, and (iii) dissemination of research results and concepts to the interested public.

IZA Discussion Papers often represent preliminary work and are circulated to encourage discussion. Citation of such a paper should account for its provisional character. A revised version may be available directly from the author. 


\section{ABSTRACT \\ Financial Liberalization and Democracy: The Role of Reform Reversals*}

The relationship between economic and political liberalization has received a great deal of attention lately, yet the possibility of a nonlinear relationship and the role of reversals remain largely neglected. Focusing on democratization and financial reform, this paper offers evidence for a $U$-shaped relationship across countries, over time as well as in a panel setting using a wide range of estimators for various reform measures. We link this non-linear relationship to the notion of partial or captured democracy. We provide as well econometric support showing that even when de facto is modelled as a function of de jure financial liberalization, this non-linearity obtains.

JEL Classification: C23, D72, O38, P16

Keywords: reform reversals, political liberalization, economic liberalization, financial reform

Corresponding author:

Nauro F. Campos

Department of Economics and Finance

Brunel University (West London)

Uxbridge UB8 3PH

United Kingdom

E-mail: nauro.campos@brunel.ac.uk

\footnotetext{
* We thank Enrica Detragiache, Elias Papaioannou and seminar participants at the 15th World Congress of the International Economic Association (Istanbul), at the Development Workshop in Clermont Ferrand, at the Seminar of Development and Globalization at University of Paris 1-Sorbonne, and at the CEPR-Fondazione Debenedetti Conference "Reforms without Prejudice", Milan. We also thank Lenka Gregorova for the excellent research assistance. We are responsible for all remaining errors.
} 


\section{Introduction}

We shall not be diverted from our course. To those waiting with bated breath for that favourite media catch-phrase, the U-turn, I have only this to say. You turn if you want to. The lady's not for turning.

Lady Margaret Thatcher

Starting in the 1990s and continuing in the first decade of the $21^{\text {st }}$ century, there has been acceleration at the world level to both the process of democratization and to the process of financial liberalization. A relevant issue is whether the global financial and economic crisis that started in 2007 could determine a slowdown or even a reversal in the process of financial liberalization around the world, and especially in emerging economies. Previous literature has indeed found a significant adverse impact on financial reform coming from recessions and banking crises (Abiad and Mody, 2005). Furthermore, financial reform experienced a "great reversal” in the aftermath of the great depression of 1930s.

The political dimension of financial reform has been emphasized in the literature. Rajan and Zingales (2003) argue that incumbent firms may block, or even reverse, financial reform as financial development improves the conditions for entry of new firms and thus increase competition, challenging rents of the incumbents. Incumbents can in turn form blocking elites and pressure governments to retard or reverse financial reform. Full-fledged democracy might be an antidote to the power of blocking elites, as under full democracy governments are accountable to the whole population. Less clear is what happens away from full-fledged democracy. Is the power of blocking elites linearly increasing, or there could be a non-linear relationship between degree of democracy and power of economic elites? Is it conceivable that the power of economic elites reaches its peak in intermediate regimes, regimes of "partial democracy", in which economic elites "capture” the government because maybe in autocracies political elites have greater power than economic elites? 
Therefore, away from full democracy, democratization may in fact slowdown or even reverse economic reforms. We find strong evidence of a non-linear relationship between democracy and financial reform, which suggests that the lowest level of financial reform tends to occur in intermediate regimes of "partial democracy". The non-linearity implies as well that during a process of democratization, as the system travels from autocracy to partial democracy financial reform can go through reversals (Figure 1.) In this paper we focus explicitly on such non-linear relationship and on the reform reversals they underscore. ${ }^{1}$

When non-linearities matter, the effects of changes in the political regime on financial reforms depend on initial conditions. Cross-country analyses involving countries with highly heterogeneous starting points may generate misleading results. We tackle this identification problem by choosing a specific set of countries, the transition countries of Eastern Europe and former Soviet Union. Transition countries provide a unique natural experiment situation. The variation in the level and type of political competition across these 25 countries in the starting point of the sample, early 1989, is minimal and the same can be said in terms of financial liberalization. Following the common initial condition the sample displays significant variation in both political and financial variables. Indeed, after the collapse of communism, these countries followed radically different economic and political trajectories (Campos and Coricelli, 2002).

Using the full sample of transition economies with yearly data for the period 1989 to 2005, our main conclusions are as follows. Firstly, there is strong "unconditional” evidence of non-linear association between economic and political reforms. This obtains using different measures of the two reforms, over time, across countries and in a panel setting. Secondly, we provide a novel explanation which is based on a three-regime model that emphasizes the risks

\footnotetext{
${ }^{1}$ Although the preponderance of reversals may have escaped scholars, it has surely not eluded politicians. Not even the "Iron Lady," UK Prime Minister Margaret Thatcher. Plentiful evidence, the above quote notwithstanding, is available on the starts-and-stops of various reforms during her time in office.
} 
that along transitions from autocracy to democracy countries can get stuck in an equilibrium with incomplete democracy and incomplete economic reforms. Thirdly, we provide evidence that incorporating this U-shaped relationship into a standard model of financial reform has two main benefits. The first is that it strengthens the finding of the U-shaped relation (thus providing “conditional” support to this finding) and, second, it improves the fit of this model as the estimates of the other crucial variables turn out to be significantly more precise.

Finally, we estimate an empirical model in which de jure measures of financial reforms are an input into de facto measures. We find that de jure measures affect de facto measures. Political variables still have a non linear effect on de facto financial reform even after controlling the role of de jure measures. This suggests that the political regime plays a fundamental role in the implementation and enforcement of legislation rather than solely on the legislation itself. ${ }^{2}$

The paper is organized as follows. In section 2, we discuss the data set and different measures of political and financial liberalizations. In section 3, we present econometric evidence for the so-far neglected stylised fact of non-linear relationship between political and financial reforms and reform reversals. The evidence shows that this holds across countries, over time, in a panel setting as well as within a standard model of financial reform determinants. In section 4, we discuss analytical issues and try to throw light on the conditions under which a country falls into a "reversals trap" (a situation in which not only political and economic liberalization co-exist, but also reinforce each other.) An Appendix provides a formal and more technical discussion of these main ideas. Section 5 concludes.

\footnotetext{
2 Although in this paper we stress the de jure vs. de facto differences in terms of financial liberalization, we also note that recent studies contrast de facto to de jure political reform (Acemoglu and Robinson, 2006). Our empirical analysis distinguishes these two aspects but find that the differences are not strong enough to affect our results.
} 


\section{Political and Financial Reforms: What does the data show?}

This section presents the data we put together for this paper: we construct objective (replicable) indicators of financial liberalization as well as of political reform for a yearly panel of 26 countries from 1989 to 2005 . We also try to put forward as wide an array of indicators as possible so as to not only do justice to the multi-faceted nature of these two processes, but also to reflect some of the most pre-eminent concerns in these literatures.

We first discuss the indicators used to capture the various dimensions of financial reforms (Levine, 2005). In particular, we try to account for the contrast between the size of the financial sector and its efficiency (needless to say, the latter is the favoured measure while the former is the measure that has a longer use and tradition.) We thus construct one indicator for each of these dimensions.

Our indicator for the "quantity of financial services" is based on three components: the ratio of liquid liabilities to GDP, the ratio of credit to the private sector to GDP, and the ratio of commercial and Central bank assets to GDP. ${ }^{3}$

In order to combine these variables into a single indicator, we normalize them by equating the maximum (for all countries and all years) of each component to one. We calculate the distance from each country-year data point to the global maximum (normalized to one) by (a) subtracting each country-year data point from the overall minimum (by overall we mean for all countries and all years), (b) calculating the range for each series (that is, maximum minus minimum), and (c) dividing the results from (a) by those from (b). We use this normalization for the political and economic (financial) reforms measures. In our view, this is superior to alternatives that use a subjective yardstick because, inter alia, we do have a few countries in the last years of our sample (most of the new European Union members) that have actually completed economic and political reforms and that are already considered full-

\footnotetext{
${ }^{3}$ Data are from the electronic version of the IMF's International Financial Statistics.
} 
fledged market economies and liberal democracies.

Our index of financial sector efficiency is based upon two variables, obtained from the BankScope database. The first is the ratio of bank overhead costs to total assets which is defined as the accounting value of a bank's overhead costs as a share of its total assets. The second is the net interest margin which is the accounting value of a bank's net interest revenue as a share of its interest-bearing assets. Because in these two cases, larger values indicate less competition and "less reform," for consistency in step (a) of the normalization described above we subtract each country-year data point from the overall maximum.

From Figure 2 we can see that according to our indicators, average financial efficiency has been highest in countries like the Czech and Slovak Republics, Hungary and Albania, has been lowest in countries like Moldova, Georgia and Belarus, with intermediate average levels of efficiency shown in countries like Russia, Armenia, and Croatia. ${ }^{4}$

Figure 3 show that our financial efficiency index reveals a variety of over time trajectories. Of particular interest is that they also show that reversals abound. Figure 3 presents three selected examples. The first is Poland where the financial reform index (in the vertical axis) increases from 1989 to 1992, then shows a small decrease until 1996, and then a further increase until the year 2005. The second panel in Figure 3 is for Russia and shows a rather different trajectory over this 15-year period: financial efficiency decreases from 1991 until 1995 and then increases without reversals until 2005. The third and last panel shows the experience of Uzbekistan, a case in which our index reveals a constant deterioration of financial efficiency from 1991 to 2005, with only the period 2000 to 2004 showing signs of relative improvements (which were wiped out from 2004 to 2005).

\footnotetext{
${ }^{4}$ Data on financial reform is available for all transition economies, except for Tajikistan and Turkmenistan. Guergen et al. (1999) note that both countries have announced widespread financial reform packages in 1997-1998. Political reform, on the other hand, is still extremely restricted in Tajikistan until today and was so in Turkmenistan until the death of President Niyazov in late 2006. Our feeling is that if we could incorporate these two countries to our analysis, it would much strengthen our results. This is because according to the limited available information, we would place the two countries just below Uzbekistan.
} 
It is our view that this index of financial efficiency is preferable to the index that captures the size or depth of the financial sector. For the sake of space, we report a direct comparison of the two indexes only in the regression analysis in the next section.

Let us now turn to the measures of political liberalization. Our aim was again to put forward a wide array of measures capturing various aspects of political reform. The first measure we collect is political rights from Freedom House. This variable is coded in a 1 to 7 scale (with 1 indicating highest level of political rights and 7 the lowest level of political rights) and covers three main areas: the electoral process, political pluralism and participation, and the functioning of the government. The Freedom House civil liberties measure uses the same scale and reflects freedom of expression and belief, associational and organizational rights, rule of law and personal autonomy and individual rights. The Freedom House democracy index is a categorical variable based on the combination of these two last variables. More precisely, countries whose political rights and civil liberty ratings average 1 to 2.5 are considered free, 3 to 5.5 partly free, and 5.5 to 7 not free. Notice that in the cases of political rights, civil liberties and democracy, higher values indicate less democracy, rights and liberties. We also collected another, finer, democracy variable from the Nations in Transit report also published by Freedom House. The Nations in Transit democracy variable is coded in a scale of 1 to 7 (with 1 highest and 7 lowest) and reflects four dimensions: the electoral process, civil society, independent media and governance. Finally, we also use a measure of de jure presidential powers, the Presidential Power Index. ${ }^{5}$

We generate a composite index of political reform, using the same normalization applied to the financial reform measures, and combining Freedom House's Civil Liberties and Political Rights, Nations in Transit Democracy and the Presidential Power Index. In similar

${ }^{5}$ The index is based on whether 29 powers are established by the constitution and coded as follows: 1 - if the president holds exclusively a given power; 0.5 - if the president is sharing a power with another body; and 0 - if the president does not hold the power under question. The data are from Careja et al. (2006). 
fashion, we conduct our analysis using both the index and its individual components. Figure 2 shows the average over time for each component for each country, while Figure 3 show the time-series behaviour of our composite index of political reform.

Figure 2 shows that Slovenia, Czech Republic and Hungary are countries that score high in terms of political reforms, while countries like Uzbekistan, Azerbaijan and Kazakhstan receive low scores (recall that due to data availability, Turkmenistan and Tajikistan are excluded.) Figures 3 show that there is considerable time-series variation in these indicators and that, as was the case with financial liberalization, reversals are plentiful. For instance, political reform in Poland peaked between 1990 and 1997, with relative levels of political liberalization declining until the end of the sample. In the case of Russia, our data show that relative political reform declines continuously from 1991 to 1993, and then again from 1997 to 2005. Finally, Uzbekistan achieved its maximum level of political liberalization in year 1991.

Figure 4 focus on reform reversals. For comparability, the two reform indices are normalized to $0-1$ and re-scaled so that higher values reflect more reform. We define reform as the changes in levels of the two indicators (first-differences), measured on a year-to-year basis. We associate a reversal to the case when the value of this change is negative. Using this definition, out of the 337 country-year cells for which data on the two reforms is available, we identify political reform reversals in $48 \%$ of the cases, we detect financial reform reversals in $35 \%$ of the cells, and joint political and financial reform ("twin") reversals in $17 \%$ of all possible cases.

As it can be seen in Figure 4, we can identify reversals in political or in financial reforms in every single country in our sample. Moreover, we do not observe joint reversals in only 4 countries among those for which data on the two reforms exist (namely, Estonia, Kygyz Republic, Moldova and Romania.) 
Regarding the magnitude of reform reversals and keeping in mind that both reform indices are on a 0 to 1 scale, the value of the average change is 0.008 (for political reform) and 0.02 (for financial reform) with respective standard deviations of 0.09 and 0.07 . In terms of ranges, the largest advance in a single year in financial reform (0.56) was for Croatia towards the end of the war in 1994 and in terms of political reform, the largest increase $(0.77)$ was for Czechoslovakia in 1990. We find the largest reversal in a single year in terms of financial reform was for Russia in 1995 (-0.34) while in terms of political reform it is observed for Tajikistan in 1992 (-0.33). These suggest that reversals are common and rather severe.

\section{Econometric Evidence}

This section discusses our main econometric results. They try to establish and evaluate the empirical existence and robustness of a non-linear relationship between political and economic (financial) liberalizations. Below, we present four main pieces of empirical evidence: (1) from the "between" panel estimator and focusing on the simple, bivariate, relationship between political and financial liberalization, (2) from the fixed-effects estimator focusing on the cross-country, over time relationship between the two reforms, (3) from a structured model of the determinants of financial liberalization (Abiad and Mody, 2005), and (4) from instrumental variables panel estimates accounting for the relationship between de jure and de facto dimensions of financial liberalization.

\subsection{Between Estimates}

Here we investigate the extent and depth of empirical support for the often neglected fact that the relationship between economic and political liberalization follows a U-shaped pattern. We do this, firstly, by focusing on the simple averages over the whole period for each country 
(that is, the "between" panel estimates).

Figure 2 plots the results from the "between" panel estimates. These are obtained by regressing the various measures of political reform on our preferred measure of financial reform (that is, the one reflecting efficiency, not depth or size of the financial sector). More specifically, Figures 2 plots the predicted and actual values from regressions of the country averages of political rights (plots for various measures of political reform are in the Appendix) on linear and quadratic terms of our index of financial efficiency. The fit of the quadratic specification is better than that of the linear for every measure of political reform.

As it can be seen in Figure 2, the relationship between financial reform and political reform is clearly U-shaped. This obtains for a whole range of political reform measures, namely for the cases of civil liberties, political rights, two democracy indexes, and press freedom.

The figure also shows where each country is placed in the economic and political reform space. It is important to keep in mind that the figure has averages over the whole period for which data is available (it generally starts in 1989 for Central European and in 1991 for former Soviet Union countries) and that data is missing for countries such as Turkmenistan and Tajikistan which tend to score high in financial development and low in political. ${ }^{6}$ It can be seen that countries such as the Czech and Slovak Republics and Hungary have high levels of financial and political reform, while at the other extreme for countries such as Uzbekistan, Azerbaijan and Armenia we observe high average levels of financial reform but little in terms of political liberalization. In between, we have countries that have made some limited progress on each of the two reforms, with some having made more inroads in political than in economic reforms (e.g., Romania and Georgia) and others having made

\footnotetext{
${ }^{6}$ We have also estimated the regressions below without Uzbekistan in order to check whether this country was solely responsible for the U-shaped relationship and we find that the results are not at all affected (with or without Uzbekistan).
} 
relatively more progress in terms of economic than in terms of political reforms (e.g., Albania and Russia).

These averages present a reassuring picture and are a good start, yet they may be concealing some important differences. As can be seen in Figure 3, examining the trajectory of country by country in terms of their progresses in political and economic reforms over time shows that reversals do not seem scarce. They are also not restricted to a specific reform: reversals tend to occur in both political and financial reforms. Moreover, these also suggest that political reversals seem to be related to reversals in financial reform albeit there are obvious differences in terms of the intensity of such reversals. For example, in the case of Poland and Russia, political reversals seem to be larger than the economic reversals, while for Uzbekistan the opposite seems to be the case. Although one can learn quite a bit from these simple graphs, to strengthen the case for reversals as a stylised fact of reform, further systematic econometric evidence is provided below.

\subsection{Fixed-Effects Estimates}

Table 1 presents fixed-effects panel estimates for the relationship between political and financial reforms. As noted, we run the opposite specification from that underlying Figure 4, with financial reform now in the left-hand side. The first five columns of Table 1 report the results for each of the components of the two indexes of financial reform (namely, depth and efficiency, or index 1 and index 2 in the Table). Columns 1 to 3 show the results for the components of Index 1 (financial depth), columns 4 and 5 show the results for the components of Index 2 (financial efficiency), while columns 6 and 7 show the results for Index 1 and Index 2 as the chosen dependent variables.

In interpreting the results, notice that the original components of political and of 
economic reforms were not re-scaled. ${ }^{7}$ Thus, these results suggest that there is a non-linear relation between political and financial reform and that this relation is U-shaped: democracy first decreases and then increases with financial reform (indeed, this occurs irrespective of which financial reform index we may concentrate on or of which individual component of any of the two financial reform indexes).

These econometric results are equally strong for civil liberties and for the Nations in Transit's democracy index as they are for press freedom. For these three aspects of political liberalization, a strong U-shaped relationship emerges whether we focus on any of the aggregate financial reform indexes or on any of their five individual components. The results for the presidential power index and for political rights are somewhat not as strong. For the presidential power index, the U-shape relationship obtains only for the case of the Index 2 of financial reform, the one capturing efficiency. For political rights, the U-shaped relationship actually obtains for the two aggregate financial reform indexes, but it is weaker for index 1 than for Index 2 as it fails to obtain for the first two individual components of index 1 . This is not a major concern because they all occur with respect to index 1 , which is not the preferred measure of financial reform as explained above.

\subsection{Reform Reversals in the Abiad-Mody Model}

Above we present results supporting an “unconditional U-shaped” relationship between political and economic reform reversals. "Unconditional” because it does not depend on any other potentially important explanatory variable. Yet one concern is that the omission of other important determinants of any of the two reforms may bias these results. In order to minimize this issue, we selected one well-known econometric model of the determinants of financial liberalization and asked what would be the consequences of enlarging it with political reform.

\footnotetext{
${ }^{7}$ This is also one way of seeing that this normalization is not artificially "creating" this U-shaped relation.
} 
The main objective of Abiad and Mody (2005) is two-fold: to create an index of financial liberalization across countries and over time, and to study how different political economy theories of reform succeed in explaining the dynamics of such indicator. ${ }^{8}$

Their financial liberalization index is constructed for 35 (developing and developed) countries, annually from 1973 to 1996 . The components of their Financial Liberalization Index are as follows: credit controls, interest rate controls, entry barriers in banking, operational restriction on banks (e.g. branching regulations), privatization, and restrictions on international financial transactions (e.g., multiple exchange rates.) For each dimension in each year, a country receives a score on a graded scale, with zero being "fully financially repressed," one "partially repressed,” two "largely liberalized" and three "fully liberalized.” Theirs is a de jure type of measure, while ours is a de facto measure of reform. ${ }^{9}$ The next subsection investigates how these two de jure and de facto dimensions are related and whether their relationship affects the finding of a non-linear relationship between economic and political reforms.

The empirical model from Abiad and Mody (2005) nests the main hypothesis from the political economy of reform literature. They argue that the various determinants of reform fall into the following categories: (a) shocks such as crises of various types; (b) learning about the effects of previous reforms, (c) ideology of those in charge of setting the agenda, negotiating political support and implementation, and (d) the political and economic structures which conditions the decision to embark in a given reform programme.

Their baseline econometric specification has financial reform as a function of a learning term reflecting the initial level of reform and the convergence effect between actual and desired level of reform. Moreover, Abiad and Mody (2005) also include various factors to

\footnotetext{
8 Notice that their sample does not include any transition economy so unfortunately there is no overlap between their sample and ours.

${ }^{9}$ This is a crucial distinction in the financial liberalization literature (Kose et al, 2009).
} 
reflect the role of shocks, namely balance-of-payment crises, banking crises, recessions and high-inflation periods. The influence of international financial institutions is assessed through a dummy variable for participation in an IMF program and that of global factors is proxied by the U.S. interest rate. For the political orientation of the government, they include dummy variables for left-wing and right-wing governments (“center” being the omitted category). The political and economic structured is proxied by the degree of trade openness of the economy.

In this paper, we tried to replicate their model as closely as possible. We collected data on all the explanatory variables in Abiad and Mody and measure them in exactly the same way as they did. There are only three relatively small differences. They include a dummy variable for the political honeymoon period, the first year of a new government in office. During this period, the implementation of painful reforms is said to be easier because the newly elected government has political capital to spend. We could not include this variable in our specifications because, unsurprisingly, it turned out to be correlated with our political reform index. The second change was that Abiad and Mody also add a regional element to their learning story (i.e., countries learn about reform from their regional "neighbours.”) In our case, all countries are from the same region so in our model the learning aspect only takes place over time (that is, it does not happen at different speeds within different regions.) The third and last change is that instead of trade openness we use an index of external liberalization. This also allows us also to throw some light on the relationship between different economic reforms.

Abiad and Mody find that while banking crises hinder financial reform, balance-ofpayment crises foster it. They find the initial level of reform matters. Declines in global interest rates exert a positive effect on domestic financial liberalization, but there is little evidence to suggest that recessions and high-inflation episodes are systematically associated 
with financial liberalization. Similar conclusions are reached with respect to participation in an IMF program. Finally, there is little evidence for the honeymoon political effect, for whether the government is left or right-wing and for the role of trade openness.

Table 2 presents our estimates of the Abiad-Mody model of the determinants of financial reform. First we report the tobit panel estimator because our financial reform index (the left-hand side variable) is constrained to the 0 to 1 interval. We report results for our financial efficiency index and our overall political reform index. In order to minimize concerns about reverse causality, we lagged all variables by one-period (except political reforms, although we find that lagging these makes the estimates substantially more precise.)

As it can be seen in Table 2, our findings are similar to those from Abiad and Mody (2005). Debt crises help financial reform, while banking crises hinder it. Lower U.S. interest rates boost domestic financial reform, while recessions and high-inflation show a systematic negative effect on financial reform. The results also show that the coefficients on IMF program, left-wing and right-wing are not statistically significant different from zero.

Yet the more important result from Table 2 is that the two terms for political reform are significant throughout and carry the signs we expect. Thus, the result shows that the relationship between financial and political reforms is indeed U-shaped.

Table 3 uses the same specifications but now for the fixed-effects panel estimator. As it can be seen, there is no change in the main conclusions. We are able to replicate Abiad and Mody main findings and show that incorporating political reform is important to improve the predictive power of the model.

Table 4 brings some very important differences. Chiefly among them is that now our left-hand side variable is change in the levels of reform (that is, the first-differences of our financial reform index). Moreover, we now cluster the standard errors at the country level in order to account for country-specific errors. As it can be seen, the results are slightly worse 
than above in that a few of the variables loose statistical significance (although most of the signs are still consistent). Among the results which remain, we find that debt crisis spurs while recession dampens financial reform. Interestingly, now we find that left-wing governments are, ceteris paribus, more likely to implement financial reforms than right-wing and centre governments. More importantly, we find that political reform is still a powerful variable explaining the evolution of financial reform across countries and over time, and that this relationship seems indeed to be U-shaped.

The estimates in Table 4 are our preferred estimates. GMM estimates have been used widely but criticized heavily recently, inter alia, because of its somewhat mechanic process of selecting instruments. Table 5 report standard GMM estimates of the same specifications as before for the sake of an additional robustness check. As it can be seen, the support for our hypothesized relationship between political and financial reforms is unabated. The GMM results also support the contrasting effects of banking and debt crises, the negative effects of U.S. interest rates, high-inflation and recessions, and now even of both the role of left- and right-wing governments.

\subsection{Instrumental Variables Estimates of De Jure and De Facto Financial Liberalization}

This sub-section presents another way of assessing the robustness of the non-linear relationship between political and economic liberalizations. One of the central distinctions in the literature on financial liberalization is that between de jure and de facto measures (Kose et al, 2009). De jure measures reflect changes in the legal framework, laws, rules and regulations that affect the financial system, while de facto indexes capture the size and actual workings of the financial system. The index we developed and used above is therefore a de facto index, while Abiad and Mody's is a de jure measure. Kose et al. (2009) argue that many discrepancies in the literature on the impacts of financial liberalization can be traced back to 
this distinction.

One natural extension would be then to ask whether our results hold if instead of de facto we use de jure measures. However, instead of just substituting different types of measures, we investigate an that has been largely unexplored, namely how de jure affects de facto liberalization. We think of this issue in a production function type of framework. Specifically, we posit that de facto financial liberalization may be driven by two components: one is changes in laws and regulation (inputs) and the other is changes in the quality of the enforcement of these laws (or "technology"). The question we then address in this sub-section is whether the non-linear relationship between political and economic (financial and de facto) liberalizations obtains even when we take into account the role of the legal inputs into this process.

The original index by Abiad and Mody (2005) has been updated by Abiad et al. (2008) and extended to many more developed and developing countries, 16 of which are in our sample. The revised Financial Liberalization Index captures seven factors: (a) capital account restrictions, (b) interest rate controls, (c) competition (entry barriers in banking), (d) banking supervision, (e) privatization (and state involvement in the financial system), (f) capital flows restrictions, and (g) policies to develop securities in stock markets. One main source of data is the IMF's Annual Report on Exchange Arrangements and Exchange Restrictions (AREAER).

Table 6 presents instrumental variable estimates using these data. Panel A of Table 6 contains the second-stage regression in which changes in the de facto measure of financial liberalization is regressed on, as before, lagged level of de facto liberalization, linear and square terms for political liberalization and, now added, the variables reflecting Abiad et al.’s financial liberalization reforms. The latter enter one-by-one (results for each of the seven components are presented in each column). Columns 1 to 7 contain each one of the seven components described above, while column 8 contains the results for the aggregate de jure 
index of financial liberalization. Panel B at the bottom of Table 6 contains the first stage results for the de jure measures, using the Abiad and Mody specification as in section 4.3. For example, column 1 in panel B shows the first-stage results for capital controls as the endogenous variable: column 1 shows our IV results for the case in which capital controls enters the de facto reform equation (Panel A), with capital controls instrumented following the original Abiad and Mody model (Panel B).

As expected, the variables in the Abiad and Mody model as a whole are strong predictors of the inputs or de jure measures of financial liberalization. Table 6 reports the $\mathrm{F}$ statistic for the excluded regressors, that is significant in all cases. The Hansen's $J$ statistic according to which the null hypothesis that instruments are valid, uncorrelated with the residuals and thus correctly excluded from the second stage regression is also supportive.

There are four main results from Table 6 . The first is that there is further evidence for a non-linear relationship between political and economic reforms. The two coefficients on political reform, linear and square, are statistically significant in all but one case (column 7, for the stock market policies component). Moreover, their magnitude is strikingly similar to that obtained in the preferred estimates from section 4.3.

The second important result is that the exogenous component of the de jure financial liberalization index is found to be a strong predictor of de facto financial liberalization in all cases but one, namely for competition policies in the banking sector. This suggests that actual financial liberalization seldom takes place without first a change in the relevant laws and regulations. Yet, in order to understand the dynamics of actual financial liberalization, in addition to the effects from financial reform inputs (de jure indexes), there seems imperative to also take into account political reforms.

The third important result is related to this last one: political reform has a first-order, direct impact on de facto financial liberalization and, more importantly, there is no evidence 
of any confounding indirect effect of political reforms on actual financial liberalization through changes in the laws and regulations that govern the financial sector. Our evidence shows that the main role of political reforms is to affect the enforcement of those regulations, and not the regulations themselves.

The fourth important result refers to the contrasting works of the Abiad and Mody set, which seem to work well in terms of explaining actual financial liberalization of explanatory variables (as seen in section 4.3) but it does not seem to work as well when the task is to explain de jure financial liberalization (Panel $\mathrm{B}$ of Table 6). It is difficult to find a single variable that shows a consistent effect across columns 1 to 8 , with the sole exception of trade liberalization. In the case of debt crisis, depending on which component of de jure liberalization one focuses, we can find a statistically significant, positive or a negative impact.

In summary, we find that there is strong evidence for a U-shaped relationship between political and economic reform in our data. This result is quite robust. We have used a wide array of estimators, a strong identification strategy, and various measures of the two reforms. Our basic finding successfully goes through all of these checks.

\section{Explaining the non-linearity and reversals}

A non-monotonic relationship between economic and political liberalizations requires the presence of at least three political regimes. The introduction of a regime of partial democracy, an intermediate regime between autocracy and full-fledged democracy is the key element of the non-monotonicity. We exclude cases of military dictatorship and repression, and focus on regimes based on universal voting rights and elected governments. This assumption implies that all regimes can be defined as de jure democracies, defined as systems based on universal voting rights. Thus, our definition of three political regimes refers to de facto political regimes, determined by the weight attributed to the preferences of the majority of the 
population in determining political decisions. Only in a full-fledged democracy, the majority of the population determines the decisions of the government. By contrast, in an autocratic regime the government represents a political elite that maximizes its own interests. Political elites may have their own independent preferences, different from those of specific economic elites or power groups. We assume that the preferences of the political elites can be summarized by the objective of staying in power. In order to maintain their power, political elites need sufficient political support. ${ }^{10}$ They have to build consensus in the population in order to avoid the risk of being overthrown and, at the same time, they rely on specific economic elites. Finally, in the intermediate regimes of partial democracy, the balance of power tilts towards economic elites, which are able to control the government and adopt policies that simply maximize the interests of the economic elites.

Economic elites de facto exert full control on the policies of the government and thus are not concerned with creating consensus in the population. Governments may change but the true power would be in the hands of the economic elites, and the policies implemented in a partially democratic regime simply protect the interests of the most powerful economic elites. This is the reason why this regime has been defined as "captured democracy" (Acemoglu and Robinson 2008). ${ }^{11}$

The definitions of the three political regimes are relevant to define the nature of policy reversals. We can indeed define a threshold level for an intermediate regime. To the right hand side of this threshold, there is a region in which economic elites interfere with the

\footnotetext{
${ }^{10}$ Similarly, in Acemoglu and Robinson (2006a) political regimes can be classified as a function of the power of elites: highest under dictatorship, lowest under democracy. Transition from dictatorship to democracy takes place with the extension of political rights - mainly voting rights - to larger groups of the population, historically to the middle class.

${ }^{11}$ The following quote from Epstein et al. (2006) effectively summarizes the relevance of partial democracy: "We also learn that the frontier of this line of inquiry has shifted away from the study of autocracies and democracies and toward the study of partial democracies. As we show here, the behavior of these systems largely determines the level, rate, and properties of democratization. While thus influential, partial democracies, being highly heterogeneous, are poorly understood. The study of democratization, we therefore conclude, should place them at its focus” (p. 552).
} 
political system and fully control the political process. ${ }^{12}$ Moving left and crossing the threshold, there is a region in which the State may regain power against the economic elites by strengthening the position of the political elites. In this region, the political system relies on a coalition between some elites and the population. Therefore, depending on the relative position with respect to the threshold, a lower level of democracy may reflect two different configurations of power of economic elites (Figure 1).

In summary, as the protection of positions of monopoly rights by economic elites is the main barrier to economic liberalization (Parente and Prescott, 2002), the relationship between power of economic elites and reform is linear and negative. However, the relationship between the extent of democracy and power of economic elites is non-linear, and this is why the relationship between political and economic liberalizations is non-linear. ${ }^{13}$

In summary, the non-monotonicity between political regime and economic reforms arises because the power of interest groups may be weakened either in a full-fledged democracy or in a more autocratic regime. To maintain their power, autocratic governments may favour efficiency enhancing reforms because these will increase consensus in the population and, at the same time, the resources at disposal of the political regime to buy such consensus. Such efficiency enhancing reforms may favour as well certain economic elites, which participate in a coalition with the population to support the autocratic government. Lacking support by some economic elites the autocratic government will be overthrown by opposing elites. Heterogeneity of elites is a distinguishing feature of our model and helps to explain why autocratic governments tend to implement fundamental economic reforms concentrated in specific areas, rather than ranging over a broad spectrum as in democracy. ${ }^{14}$

\footnotetext{
${ }^{12}$ This is the region that Rajan and Zingales (2003) have studied in connection with the role of interest groups in opposing financial development.

${ }_{13}$ Acemoglu and Robinson (2006b) developed a framework that may explain the non-monotonic relationship between political regimes and technological and institutional change.

14 Our approach has also some similarities with Rajan (2009), although our characterization of different political regimes is different.
} 
The financial sector is one of the areas in which autocratic governments have carried out significant reforms.

So far, we have discussed economic liberalization as one general concept. However, the focus of the paper is financial sector reform. Although it is likely that there is a positive correlation between different economic reforms, such correlation is far from perfect. In fact, in autocracy, and even more in the intermediate region of partial democracy, there is less convergence between different areas of reforms, at least in our sample. ${ }^{15}$ Economic elites may block reforms in specific areas, whereas reforms can proceed in areas where there are not strong vested interests. ${ }^{16}$ The functioning of the financial sectors may affect asymmetrically different elites. The presence of heterogeneous elites seems to be a useful assumption to understand the political economy of financial sector reform.

We see the link between the financial sector and political reforms working through two distinct channels. One can be thought as the defence of rent-seeking through barriers to financial development (in line with Rajan and Zingales, 2003). One elite benefits directly from blocking financial sector development. The other channel has to do with government revenues, as financial repression can be an important way for the state to raise revenue. ${ }^{17}$

While one elite benefits from financial repression, the other elite and the population are negatively affected. The elites controlling financial institutions have a direct interest in expanding their activities. Similarly, large manufacturing firms may need significant external finance and thus a developed financial sector. Finally, when the banking system is controlled by the State, political elites can use the banking sector as a powerful economic lever in their

${ }^{15}$ For instance in Russia, during the shift towards more authoritarian government under Putin, financial sector reform improved markedly, while competition policy stalled and large scale privatization reversed as a result of major re-nationalizations. Braga de Macedo and Olivera Martins (2008) analyze the complementarity of reforms.

${ }^{16}$ This phenomenon may be reinforced by external pressures arising from increased international integration of the economy. With economic integration there is less scope for barriers to reform and thus protection of monopoly rents tend to be concentrated in a smaller set of sectors.

${ }^{17}$ High reserve requirements or ceilings on deposit rates increase bank margins and thus taxable income from banks. 
own interest.

From the above, it is apparent that we expect financial sector development to be faster (ceteris paribus) in dictatorships than in partial democracies. Both autocratic and democratic governments tend to foster financial development (see the Appendix for a simple formalization of these ideas). Reversals in financial liberalization, however, are more likely in the transition from an autocratic regime towards a more democratic regime. Full-fledged democracy seems to be the best antidote against reversals. However, power groups may gain strength even in democracy and push for reversals of financial sector reform, in order to create barriers to entry and protect their monopoly positions as incumbents (Rajan and Zingales, 2003). Furthermore, the nature of financial sector reform in dictatorships is likely to be different from the one in democracies. Rather than financial reform geared towards increasing competition in the system, dictatorship may aim at financial sector reforms that increase the power and the revenue of political elites in the economy. ${ }^{18}$

\section{Conclusions}

This paper presents novel theoretical motivation and strong and robust econometric evidence for a non-linear, U-shaped, relationship between financial liberalization and political reform, which stresses the previously neglected yet crucial role played by reform reversals. We believe this to be the main contribution of the paper, which is supported by an identification strategy based on a group of countries, the so-called transition countries, which shared the same initial conditions, characterized by extremely low levels of political and economic liberalization (thus with the pre-reform periods acting as control in the analysis of the reform periods). Furthermore, we introduced a new perspective on the relationship between de jure

${ }^{18}$ An interesting area for future research is the analysis of the different nature of financial sector development in connection with democracy, economic opportunity and more open societies. Recent work in the finance literature (Demirguc-Kunt and Levine, 2007) has emphasized the importance of the formal financial system in affecting "the degree to which economic opportunities are defined by talent rather than by parental wealth and social connections. 
and de facto financial liberalization. Rather than choosing one of the two measures, we used the de jure liberalization as an input for the de facto liberalization. It turned out that political regimes play a crucial role in affecting the implementation stage, namely the effectiveness with which de jure reforms are transferred into de facto financial liberalization.

We plan to extend the analysis in three main directions: towards a deeper understanding of the nature of the political and of the economic reversals, on how complementarity among reforms (or the lack of) affects the occurrence and severity of reversals, and we would like to analyze the impact that financial and economic liberalizations have on overall economic performance (taking into account the role of reversals in defining their joint dynamics). On the nature of reversals, we are interested in assessing whether their size and duration systematically vary across political regimes and types of economic reforms. We also plan to carry out our analysis for a larger set of economic reforms and study as well the complementarity between different reforms. Our conjecture is that different political regimes not only imply different depth of specific reforms but also a different range or choice of reforms. Complementarity between different reforms implies that the effects of specific economic reforms on overall economic performance depend on the implementation of a set of (complementary) reforms. Finally, we plan to use recently developed counterfactuals construction methods to analyze the impacts of economic and political liberalizations on overall economic performance. 


\section{References}

Abiad, A. and Mody, A. (2005), “Financial Reform: What Shakes It? What Shapes It?” The American Economic Review 95(1): pp. 66-88

Acemoglu, D. and J. Robinson (2006a), Economic origins of dictatorship and democracy, Cambridge University Press.

Acemoglu, D. and J. Robinson (2006b), "Economic backwardness in political perspective”, American Political Science Review, 100, 115-131.

Acemoglu, D. and J. Robinson (2006c), "De Facto Political Power and Institutional Persistence,” American Economic Review, 96, 325-330.

Acemoglu, D. and J. Robinson (2008), "Persistence of Power, Elites, and Institutions", American Economic Review, 98:1, 267-293.

Acemoglu, D., S. Johnson, J. Robinson and P. Yared, "Income and Democracy,” American Economic Review, 98, 808-842.

Braga De Macedo, J. and J. Oliveira Martins (2008), "Growth, reform indicators and policy complementarities," Economics of Transition 16(2): 141-164.

Campos, N. and F. Coricelli (2002) "Growth in Transition: What We Know, What We Don't, and What We Should,” Journal of Economic Literature, XL (3): 793-836.

Campos, N. and R Horvath (2006), "Reform Redux: Measurement, Determinants and Reversals,” CEPR DP 5673.

Coricelli, F. (2007), “Democracy in the Post-Communist World: Unfinished Business”, East European Politics \& Societies, Vol. 21, No. 1, 82-90

Demirgurc-Kunt, A. and R. Levine (2008), "Finance and opportunity”, World Bank Policy Research papers, n 4468.

Dewatripont, M. and G. Roland (1995), "The Design of Reform Packages under Uncertainty," American Economic Review, vol. 85(5): 1207-23.

Drazen, A. (2000), Political Economy in Macroeconomics, Princeton University Press.

Epstein, D. and P. Rosendorff (2004), “When are autocracies economically efficient?”, mimeo.

Epstein, D.L., R. Bates, J. Goldstone, I. Kristensen, and S. O’Halloran (2006), “Democratic Transitions,” American Journal of Political Science, Vol. 50, No. 3: 551-569.

Giavazzi F. and G. Tabellini (2005), "Economic and political liberalizations" Journal of Monetary Economics, vol. 52(7):1297-1330. 
Giovannini, Alberto and Martha de Melo (1993), “Government Revenue from Financial Repression,” American Economic Review 83 (4): 953-963.

Ghosal, Sayantan and Eugenio Proto (2008), “Democracy, Collective Action and Intra-elite Conflict,” Warwick Economic Research Papers No 844.

Guergen, E. Snoek, H. Craig, J. McHugh, J. Izvorski, I. and R. Van Rooden (1999), "Economic Reforms in Kazakhstan, Kyrgyz Republic, Tajikistan, Turkmenistan, and Uzbekistan,” IMF Occasional Paper No. 183,.

Haber, S. and E. Perotti (2007), “The Political Economy of Finance”, Stanford and Amsterdam, mimeo.

Kaminsky, G. and S. Schmukler (2003), Short-Run Pain, Long-run Gain: The Effects of Financial Liberalization, NBER Working Paper No. 9787.

Kose, A., E Prasad, K. Rogoff and S. Wei (2009), "Financial Globalization and Economic Policies,” CEPR DP 7117.

Leonida L., D. Maimone Ansaldo Patti and P. Navarra (2008), "Political and Economic Liberalization: Is this Relationship Non-Linear?”, mimeo.

Levine, R. (2005). Finance and Growth: Theory and Evidence. In Aghion, P. and S. Durlauf (Eds.), Handbook of Economic Growth. Elsevier, Amsterdam.

Loayza, N. V. and R. Rancière (2006). Financial Development, Financial Fragility and Growth. Journal of Money Credit and Banking, 38, 1051-1076.

Pagano, M. and P. Volpin (2008), “Labor and finance”, mimeo.

Papaioannou, E. and G. Siourounis, "Democratization and Growth", Economic Journal, 118(10): 1520-1555

Parente, S.L. and E.C. Prescott (2002), Barriers to Riches, The MIT Press.

Persson, T. and G. Tabellini, (2000), Political Economics: Explaining Economic Policy, MIT Press.

Prasad, E.S., Rogoff, K.S., Shang-Jin Wei. and M. A. Kose (2004), "Financial Globalization, Growth and Volatility in Developing Countries”, NBER Working Paper 10942.

Rajan, R.G. (2009), "Rent preservation and the persistence of underdevelopment”, American Economic Journal: Macroeconomics, 1:1: 178-218.

Rajan, Raghuram and Luigi Zingales. 2003. "The Great Reversals: The Politics of Financial Development in the Twentieth Century.” Journal of Financial Economics, 69(1): 5-50.

Rajan, R.G. and L. Zingales (2003), Saving capitalism from the capitalists, Random House. 
Figure 1: Dynamics of political and economic reforms

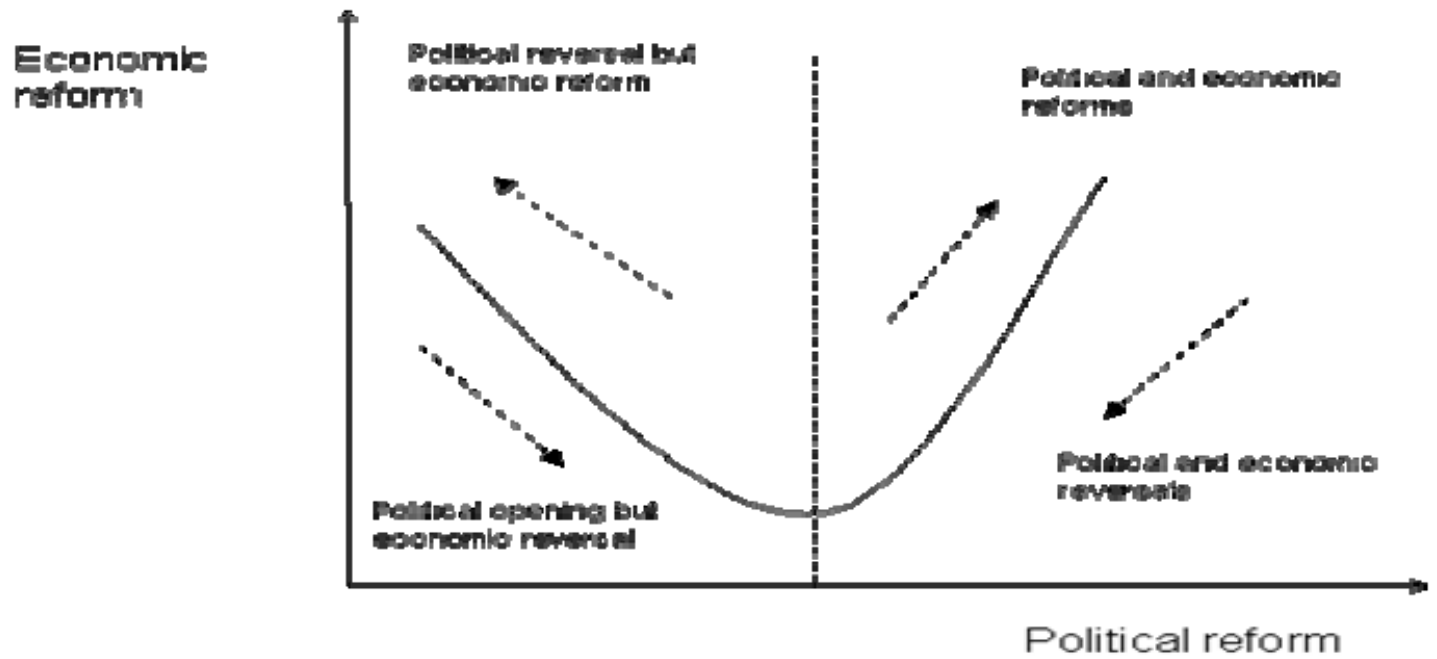

Figure 2 Cross-country evidence

Freedom House’s Political Rights vs. Financial Reform (Efficiency)

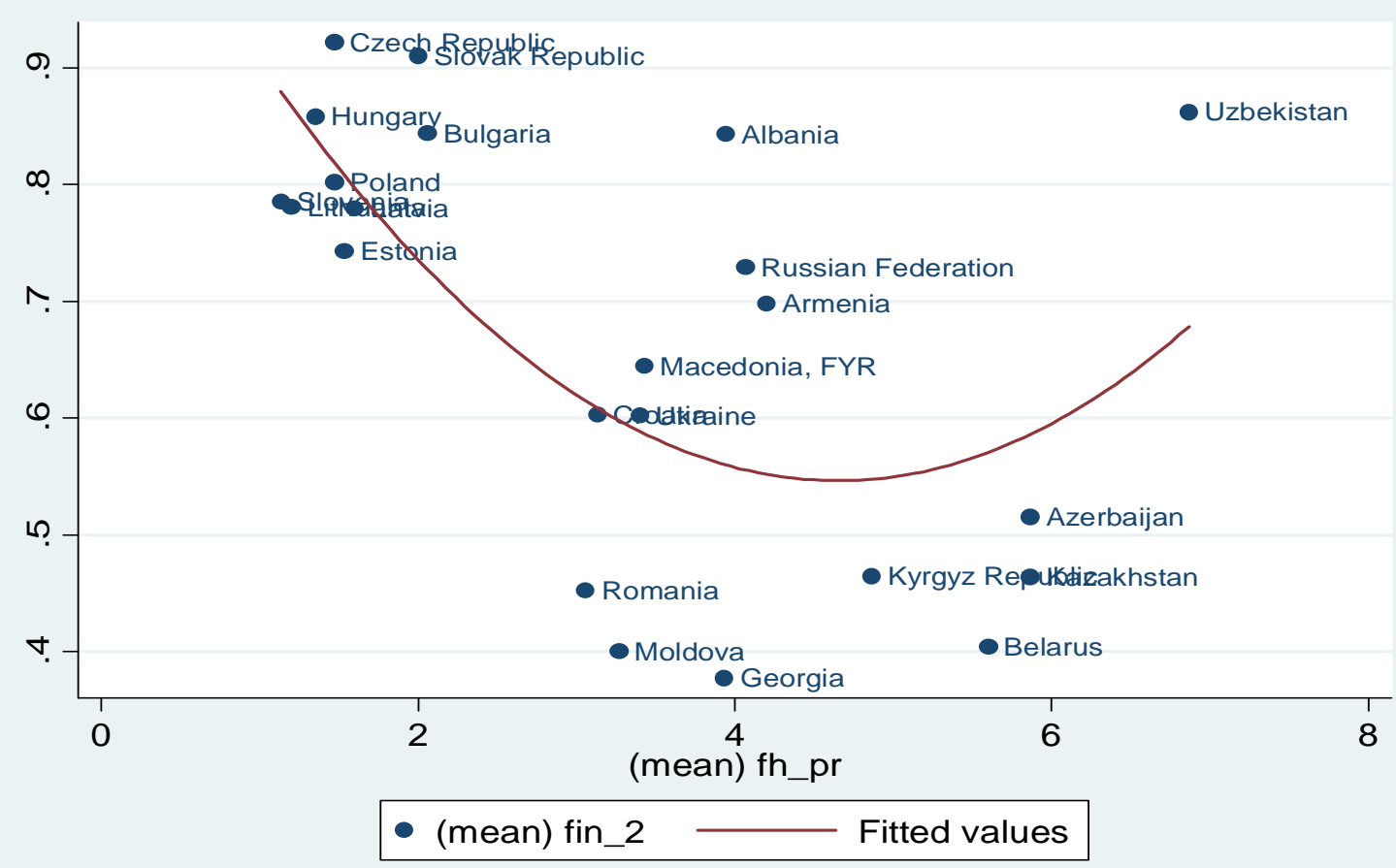


Figure 3. Time-series evidence

Poland, Russia and Uzbekistan
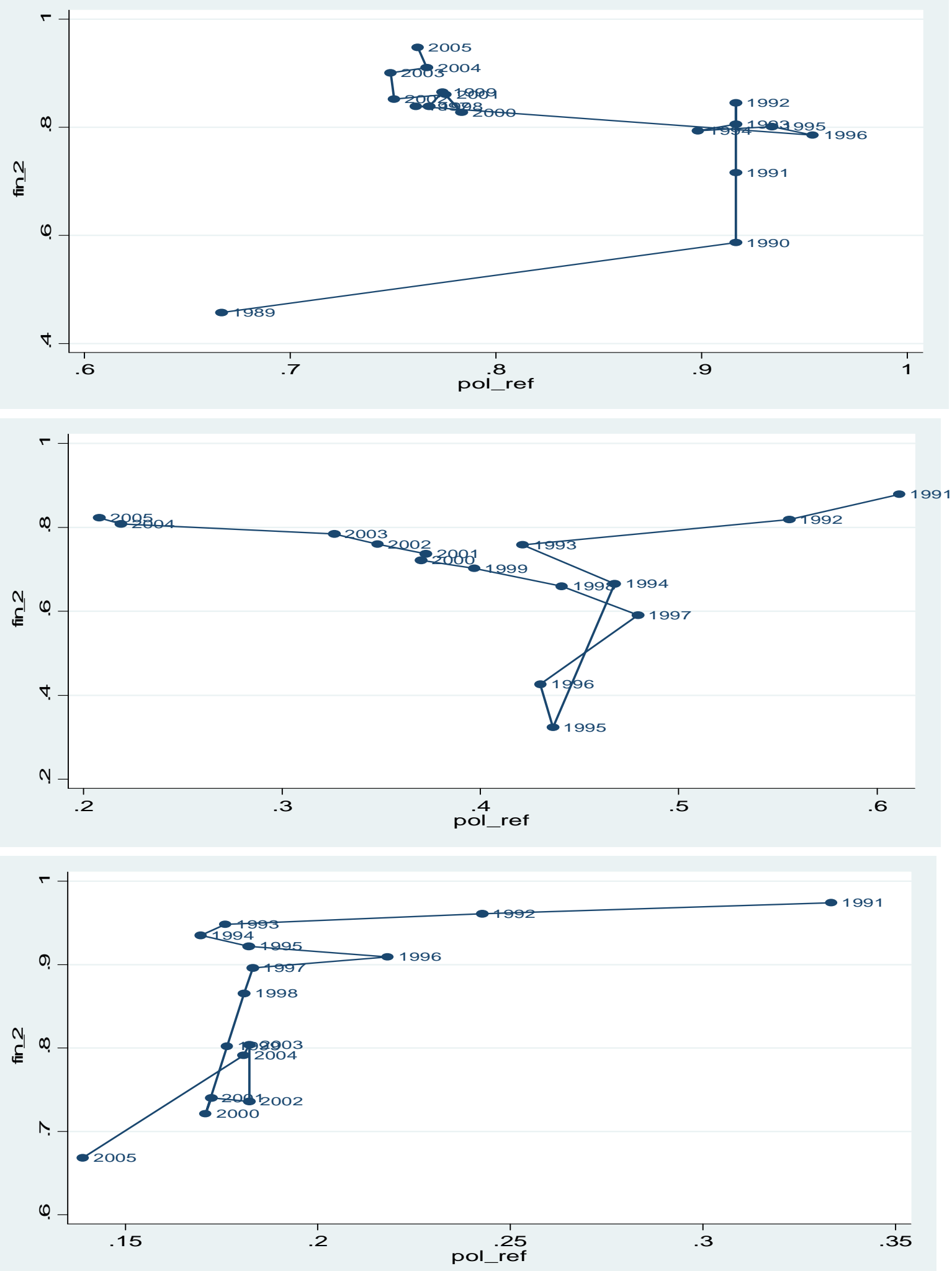
Figure 4 The Occurrence of Reversals across Countries and Over Time:

Political Reform Reversals, Financial Reform Reversals, and Twin Reversals

\section{Albania}

Armenia

Azerbaijan

Belarus

Bulgaria

Croatia

Czech Republic

Estonia

FYR Macedonia

Georgia

Hungary

Kazakhstan

Kyrgyz Republic

Latvia

Lithuania

Moldova

Poland

Romania

Russian Federation

Slovak Republic

Slovenia

Tajikistan*

Turkmenistan*

Ukraine

Uzbekistan

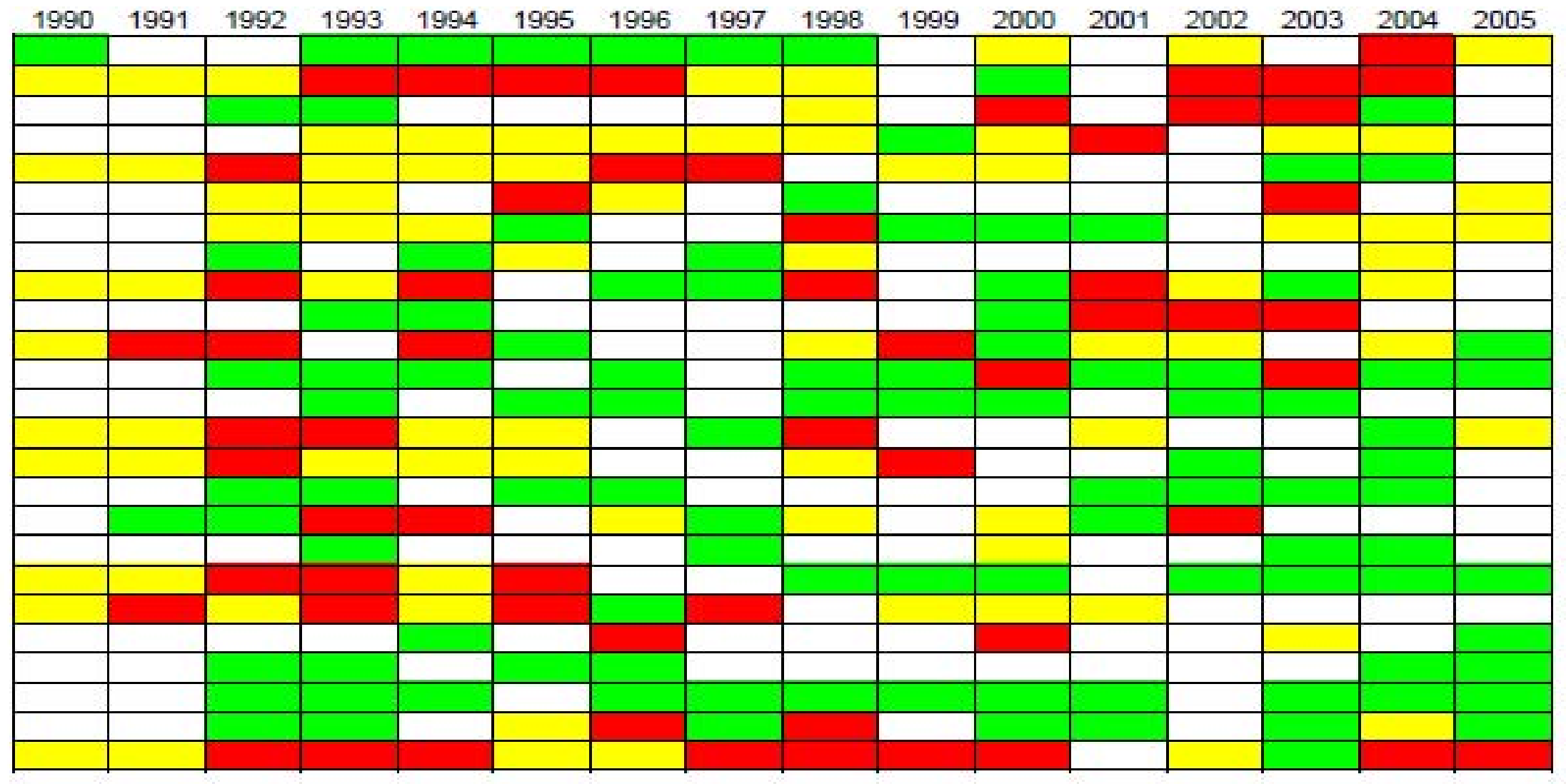

* No data for financial reform

Only financial reversal

Only political ref reversal

Twin reversals 
Table 1 Panel evidence

Fixed-Effects Estimates, 1989-2005

\begin{tabular}{|c|c|c|c|c|c|c|c|}
\hline Panel E & $\begin{array}{c}\text { Liquid } \\
\text { Liabilities } \\
\text { /GDP } \\
\end{array}$ & $\begin{array}{c}\text { Privat } \\
\text { Credit } \\
\text { /GDP } \\
\end{array}$ & $\begin{array}{c}\text { Bank Assets } \\
\text { /GDP } \\
\end{array}$ & $\begin{array}{c}\text { Bank Overhead Costs } \\
\text { / Total Assets } \\
\end{array}$ & $\begin{array}{c}\text { Net Interest } \\
\text { Margin }\end{array}$ & $\begin{array}{c}\text { Index } 1 \\
\text { First } 3 \text { vars } \\
\end{array}$ & $\begin{array}{r}\text { Index } 2 \\
\text { last } 2 \text { vars }\end{array}$ \\
\hline NiT Democracy & $\begin{array}{c}-0.165^{* * *} \\
{[0.040]}\end{array}$ & $\begin{array}{c}-0.162 * * * \\
{[0.050]}\end{array}$ & $\begin{array}{c}-0.284^{* * *} \\
{[0.062]}\end{array}$ & $\begin{array}{c}0.0411^{* * *} \\
{[0.0084]}\end{array}$ & $\begin{array}{c}0.0419 * * * \\
{[0.011]}\end{array}$ & $\begin{array}{c}-0.291 * * * \\
{[0.059]}\end{array}$ & $\begin{array}{c}-0.253 * * * \\
{[0.046]}\end{array}$ \\
\hline NiT Democracy square & $\begin{array}{c}0.0195 * * * \\
{[0.0051]}\end{array}$ & $\begin{array}{c}0.0200 * * * \\
{[0.0065]}\end{array}$ & $\begin{array}{c}0.0380 * * * \\
{[0.0078]}\end{array}$ & $\begin{array}{c}-0.00466^{* * * *} \\
{[0.0011]}\end{array}$ & $\begin{array}{c}-0.00472 * * * \\
{[0.0014]}\end{array}$ & $\begin{array}{c}0.0386 * * * \\
{[0.0076]}\end{array}$ & $\begin{array}{c}0.0300 * * * \\
{[0.0057]}\end{array}$ \\
\hline Constant & $\begin{array}{c}0.628 * * * \\
{[0.080]}\end{array}$ & $\begin{array}{c}0.489 * * * \\
{[0.090]}\end{array}$ & $\begin{array}{c}1.255^{* * *} \\
{[0.12]}\end{array}$ & $\begin{array}{l}-0.0186 \\
{[0.015]}\end{array}$ & $\begin{array}{l}-0.0167 \\
{[0.020]}\end{array}$ & $\begin{array}{c}0.970 * * * \\
{[0.11]}\end{array}$ & $\begin{array}{c}1.216 * * * \\
{[0.082]}\end{array}$ \\
\hline Observations & 170 & 170 & 201 & 197 & 197 & 171 & 207 \\
\hline Number of country & 19 & 19 & 23 & 23 & 23 & 19 & 23 \\
\hline R-squared & 0.09 & 0.05 & 0.17 & 0.21 & 0.06 & 0.16 & 0.22 \\
\hline
\end{tabular}

Standard errors in brackets ${ }^{* * *} \mathrm{p}<0.01,{ }^{* *} \mathrm{p}<0.05,{ }^{*} \mathrm{p}<0.1$ 
Table 2

AMteta1

Political reform

Political reform squared

Banking crisis

Debt crisis

IMF Programme

U.S. interest rates

Recession

High inflation

Trade liberalization

Left-wing government

Right-wing government

Constant

Observations

$$
\begin{gathered}
0.742 * * * \\
{[0.073]} \\
353
\end{gathered}
$$$$
23
$$$$
[0.17]
$$

$-0.840 * * *$

[0.24]
Number of countries

\section{Dependent variable is level of financial reform}

[1] [2] [3]

$-0.859 * * *$

$-0.0882^{* * * *}$

$[0.028]$

Note: Standard
0.0725

[0.17]

$-0.0931$

[0.14]

[0.24]

$-0.611^{* * *}$

[0.23]

$1.084 * * *$

[0.21]

$0.118 * *$

[0.21]

$-0.0552^{* *}$

[0.023]

$0.131^{* * *}$

[0.044]

0.0213

[0.021]

$-0.0200^{* * * *}$

[0.0043]

$-0.149 * * *$

[0.016]

$-0.0667$

[0.14]

[0.23]

$0.714^{* * *}$

[0.20]

$-0.0533^{* *}$

[0.022]

$0.120 * * *$

[0.044]

0.0127

[0.021]

$-0.0190 * * *$

[0.0046]

$-0.0908 * * *$

[0.022]

$-0.0695 * * *$

[0.022]

0.0623

[0.043]

$$
\text { [O }
$$

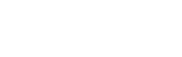
[0.072]
353

$0.911 * * *$

[0.066]

345

23

23

$01,{ }^{* *} \mathrm{p}<0.05,{ }^{*} \mathrm{p}<0.1$
$0.903 * * *$
$[0.074$
345

23
$-0.652^{* * *}$

\section{[5]}

$-0.088$

[0.14]

$-0.644^{* * *}$

[0.23]

$0.710^{* * *}$

[0.20]

$-0.0578^{* * *}$

[0.022]

$0.126^{* * *}$

[0.044]

0.0133

[0.021]

$-0.0199 * * *$

[0.0047]

$-0.0931 * * *$

[0.022]

$-0.0693^{* * *}$

[0.022]

0.0509

[0.044]

0.0314

[0.023]

$0.908^{* * *}$

[0.074]

345

23

$$
\text { [6] }
$$

$-0.0737$

[0.14]

$-0.614^{* *}$

[0.24]

$0.685^{* * *}$

[0.21]

$-0.0552^{* *}$

[0.022]

$0.121 * * *$

[0.044]

0.0116

[0.021]

$-0.0190^{* * *}$

[0.0046]

$-0.0906^{* * *}$

[0.022]

$-0.0700^{* * *}$

[0.022]

0.0576

[0.044]

$-0.0102$

[0.019]

$0.901 * * *$

[0.074]

345

23
[7]

$-0.0877$

[0.14]

$-0.647^{* * *}$

[0.24]

$0.713 * * *$

[0.21]

$-0.0577 * *$

[0.023]

$0.126^{* * *}$

[0.044]

0.0134

[0.021]

$-0.0199 * * *$

[0.0047]

$-0.0931 * * *$

[0.022]

$-0.0692^{* * *}$

[0.022]

0.0512

[0.044]

0.000833

[0.021]

0.0318

[0.025]

$0.908^{* * *}$

[0.074]

345

23 
Table 3

AMteta 1

Political reform

Political reform squared

Banking crisis

Debt crisis

IMF Programme

U.S. interest rates

Recession

High inflation

Trade liberalization

Left-wing government

Right-wing government

Constant

Observations

Number of countries

Note: Robust standarderrors in 0.09

Panel Fixed-Effects Estimates (all RHS variables lagged one-period, except political reform) Dependent variable is level of financial reform

\begin{tabular}{|c|c|c|c|c|c|c|}
\hline [1] & [2] & [3] & [4] & [5] & [6] & [7] \\
\hline 0.192 & 0.193 & 0.00418 & 0.0239 & 0.00216 & 0.0143 & 0.000686 \\
\hline$[0.24]$ & {$[0.24]$} & [0.19] & [0.19] & [0.19] & {$[0.19]$} & [0.19] \\
\hline$-0.869 * *$ & $-0.883^{* *}$ & $-0.607^{*}$ & $-0.641 * *$ & $-0.636 * *$ & $-0.574^{*}$ & $-0.609^{*}$ \\
\hline [0.38] & [0.38] & {$[0.31]$} & {$[0.31]$} & [0.32] & {$[0.33]$} & {$[0.34]$} \\
\hline $1.062 * * *$ & $1.071 * * *$ & $0.611^{* *}$ & $0.608 * *$ & $0.612^{* *}$ & $0.554 * *$ & $0.590 * *$ \\
\hline$[0.31]$ & {$[0.31]$} & {$[0.25]$} & {$[0.25]$} & {$[0.25]$} & {$[0.26]$} & {$[0.27]$} \\
\hline$-0.0813 * * *$ & $-0.0909 * * *$ & $-0.0591 * * *$ & $-0.0572^{* * *}$ & $-0.0612 * * *$ & $-0.0600^{* * *}$ & $-0.0619 * * *$ \\
\hline \multirow[t]{17}{*}[0.022]{} & [0.023] & {$[0.020]$} & [0.019] & [0.019] & [0.019] & [0.019] \\
\hline & $0.111 * *$ & $0.127^{* * *}$ & $0.117^{* * *}$ & $0.123 * * *$ & $0.119 * * *$ & $0.123 * * *$ \\
\hline & {$[0.046]$} & {$[0.036]$} & {$[0.039]$} & {$[0.039]$} & {$[0.040]$} & {$[0.039]$} \\
\hline & & 0.0262 & 0.0168 & 0.0172 & 0.0154 & 0.0165 \\
\hline & & {$[0.017]$} & {$[0.017]$} & {$[0.017]$} & {$[0.017]$} & {$[0.017]$} \\
\hline & & $-0.0206^{* * * *}$ & $-0.0194^{* * *}$ & $-0.0201 * * *$ & $-0.0194^{* * *}$ & $-0.0200^{* * *}$ \\
\hline & & {$[0.0047]$} & {$[0.0048]$} & [0.0049] & {$[0.0048]$} & [0.0049] \\
\hline & & $-0.148 * * *$ & $-0.0880 * * *$ & $-0.0898 * * *$ & $-0.0877^{* * *}$ & $-0.0895 * * *$ \\
\hline & & [0.017] & [0.022] & [0.022] & [0.022] & {$[0.022]$} \\
\hline & & & $-0.0704^{* * *}$ & $-0.0700 * * *$ & $-0.0711^{* * *}$ & $-0.0704^{* * *}$ \\
\hline & & & [0.025] & {$[0.025]$} & [0.025] & [0.025] \\
\hline & & & 0.0683 & 0.059 & 0.0615 & 0.0572 \\
\hline & & & {$[0.043]$} & {$[0.045]$} & {$[0.043]$} & {$[0.044]$} \\
\hline & & & & & -0.0153 & -0.00626 \\
\hline & & & & & [0.019] & {$[0.022]$} \\
\hline & & & & 0.0285 & & 0.0252 \\
\hline & & & & {$[0.022]$} & & {$[0.025]$} \\
\hline $0.745 * * *$ & $0.747^{* * *}$ & $0.942 * * *$ & $0.925 * * *$ & $0.927 * * *$ & $0.919 * * *$ & $0.924 * * *$ \\
\hline$[0.13]$ & {$[0.13]$} & {$[0.100]$} & [0.11] & [0.11] & [0.11] & [0.11] \\
\hline 353 & 353 & 345 & 345 & 345 & 345 & 345 \\
\hline 23 & 23 & 23 & 23 & 23 & 23 & 23 \\
\hline 0.09 & 0.1 & 0.4 & 0.43 & 0.43 & 0.43 & 0.43 \\
\hline
\end{tabular}


Table 4

\section{AMteta1}

Political reform

Political reform squared

Banking crisis

Debt crisis

IMF Programme

U.S. interest rates

Recession

High inflation

Trade liberalization

Left-wing government

Right-wing government

\section{Constant}

Observations

Number of countries
Panel Estimates (all RHS variables lagged one-period, but political reform; s.e. clustered at country) Dependent variable is change in financial reform

\begin{tabular}{|c|c|c|c|c|c|c|}
\hline [1] & [2] & [3] & [4] & [5] & [6] & [7] \\
\hline$-0.133^{* * *}$ & $-0.136 * * *$ & $-0.174 * * *$ & $-0.176 * * *$ & $-0.176 * * *$ & $-0.176 * * *$ & $-0.177^{* * *}$ \\
\hline [0.019] & [0.019] & [0.023] & [0.025] & {$[0.025]$} & {$[0.025]$} & {$[0.025]$} \\
\hline-0.106 & -0.117 & $-0.107^{* * *}$ & $-0.119 * *$ & $-0.119^{* *}$ & $-0.112^{* * *}$ & $-0.120 * *$ \\
\hline$[0.070]$ & {$[0.073]$} & {$[0.047]$} & {$[0.055]$} & {$[0.055]$} & {$[0.056]$} & {$[0.056]$} \\
\hline $0.113 *$ & $0.124^{* *}$ & $0.117^{* * *}$ & $0.119 * *$ & $0.119 * *$ & $0.112^{* *}$ & $0.115 * *$ \\
\hline \multirow{19}{*}[0.057]{} & {$[0.060]$} & {$[0.043]$} & {$[0.050]$} & {$[0.050]$} & {$[0.050]$} & {$[0.051]$} \\
\hline & -0.00299 & -0.000804 & -0.000661 & -0.000665 & -0.0037 & -0.00261 \\
\hline & {$[0.013]$} & {$[0.013]$} & [0.013] & [0.013] & {$[0.013]$} & [0.013] \\
\hline & $0.0234^{* *}$ & $0.0330 * *$ & $0.0328 * * *$ & $0.0328 * * *$ & $0.0356 * * *$ & $0.0361^{* * *}$ \\
\hline & {$[0.010]$} & {$[0.013]$} & [0.012] & {$[0.012]$} & [0.013] & [0.014] \\
\hline & & 0.00495 & 0.00285 & 0.00284 & 0.00324 & 0.00467 \\
\hline & & {$[0.0074]$} & {$[0.0076]$} & {$[0.0080]$} & {$[0.0078]$} & {$[0.0082]$} \\
\hline & & $-0.00306^{*}$ & -0.00248 & -0.00248 & -0.00327 & -0.00345 \\
\hline & & {$[0.0017]$} & {$[0.0017]$} & {$[0.0017]$} & {$[0.0021]$} & {$[0.0022]$} \\
\hline & & $-0.0328^{* * *}$ & $-0.0192^{* *}$ & $-0.0192 * *$ & $-0.0217 * *$ & $-0.0227^{* *}$ \\
\hline & & [0.0093] & {$[0.0097]$} & {$[0.0098]$} & [0.010] & [0.0099] \\
\hline & & & -0.0133 & -0.0133 & -0.0139 & -0.0128 \\
\hline & & & {$[0.012]$} & {$[0.012]$} & {$[0.012]$} & {$[0.012]$} \\
\hline & & & 0.0229 & $0.0228 *$ & 0.0107 & 0.0139 \\
\hline & & & {$[0.015]$} & {$[0.014]$} & {$[0.015]$} & {$[0.014]$} \\
\hline & & & & & $0.0193^{*}$ & $0.0230 * *$ \\
\hline & & & & & {$[0.010]$} & {$[0.011]$} \\
\hline & & & & -0.0000192 & & 0.0076 \\
\hline & & & & {$[0.0054]$} & & {$[0.0055]$} \\
\hline $0.128 * * *$ & $0.131^{* * *}$ & $0.178 * * *$ & $0.172 * * *$ & $0.172^{* * *}$ & $0.177^{* * *}$ & $0.176^{* * * *}$ \\
\hline$[0.020]$ & {$[0.021]$} & {$[0.022]$} & {$[0.028]$} & {$[0.028]$} & {$[0.029]$} & {$[0.030]$} \\
\hline 353 & 353 & 345 & 345 & 345 & 345 & 345 \\
\hline 23 & 23 & 23 & 23 & 23 & 23 & 23 \\
\hline
\end{tabular}

Note: Robust standard errors in brackets, ${ }^{* * *} \mathrm{p}<0.01,{ }^{* *} \mathrm{p}<0.05,{ }^{*} \mathrm{p}<0.1$ 
Table 5

AMteta 1

Political reform

Political reform squared

Banking crisis

Debt crisis

IMF Programme

U.S. interest rates

Recession

High inflation

Trade liberalization

Left-wing government

Right-wing government

\section{Constant}

Observations

Number of countries
GMM Estimates (Instruments: GMM is political reform and its square, IV is year dummies) Dependent variable is level of financial reform

\begin{tabular}{|c|c|c|c|c|c|c|}
\hline [1] & [2] & [3] & [4] & [5] & [6] & [7] \\
\hline$-0.543 * * *$ & $-0.467 * * *$ & $-0.754 * * *$ & $-0.677^{* * *}$ & $-0.669 * * *$ & $-0.697 * * *$ & $-0.671 * * *$ \\
\hline$[0.055]$ & {$[0.060]$} & {$[0.071]$} & {$[0.071]$} & {$[0.071]$} & {$[0.072]$} & {$[0.072]$} \\
\hline$-0.565 * * *$ & $-0.619 * * *$ & $-0.403 * * *$ & $-0.456^{* * *}$ & $-0.465^{* * *}$ & $-0.437^{* * *}$ & $-0.468^{* * *}$ \\
\hline$[0.062]$ & {$[0.067]$} & {$[0.080]$} & {$[0.078]$} & {$[0.078]$} & {$[0.079]$} & [0.079] \\
\hline $0.817^{* * *}$ & $0.874^{* * *}$ & $0.610^{* * *}$ & $0.627^{* * *}$ & $0.632^{* * *}$ & $0.604^{* * *}$ & $0.616^{* * *}$ \\
\hline \multirow[t]{19}{*}[0.054]{} & [0.058] & [0.069] & {$[0.067]$} & {$[0.067]$} & {$[0.068]$} & {$[0.068]$} \\
\hline & $-0.0961 * * *$ & $-0.0430 * * *$ & $-0.0276^{* *}$ & $-0.0253 *$ & $-0.0395 * * *$ & $-0.0335^{* *}$ \\
\hline & {$[0.013]$} & [0.014] & {$[0.014]$} & {$[0.014]$} & {$[0.014]$} & {$[0.014]$} \\
\hline & $0.138 * * *$ & $0.149 * * *$ & $0.124 * * *$ & $0.124^{* * *}$ & $0.133 * * *$ & $0.133^{* * *}$ \\
\hline & {$[0.022]$} & {$[0.025]$} & {$[0.025]$} & {$[0.025]$} & {$[0.025]$} & {$[0.025]$} \\
\hline & & 0.00876 & -0.00307 & -0.00184 & -0.0027 & 0.00222 \\
\hline & & [0.012] & [0.012] & [0.012] & [0.012] & [0.012] \\
\hline & & $-0.0201 * * *$ & $-0.0225 * * *$ & $-0.0225 * * *$ & $-0.0244^{* * *}$ & $-0.0250 * * *$ \\
\hline & & {$[0.0024]$} & {$[0.0025]$} & [0.0025] & {$[0.0025]$} & {$[0.0025]$} \\
\hline & & $-0.149 * * *$ & $-0.0808 * * *$ & $-0.0815^{* * *}$ & $-0.0846^{* * * *}$ & $-0.0882^{* * *}$ \\
\hline & & {$[0.0091]$} & [0.013] & [0.013] & [0.013] & [0.013] \\
\hline & & & $-0.111 * * *$ & $-0.110 * * *$ & $-0.112 * * *$ & $-0.109 * * *$ \\
\hline & & & [0.013] & {$[0.013]$} & [0.013] & {$[0.013]$} \\
\hline & & & 0.00182 & 0.00694 & -0.0231 & -0.01 \\
\hline & & & {$[0.022]$} & {$[0.023]$} & {$[0.023]$} & {$[0.024]$} \\
\hline & & & & & $0.0541^{* * *}$ & $0.0693 * * *$ \\
\hline & & & & & [0.012] & [0.013] \\
\hline & & & & 0.00761 & & $0.0299 * * *$ \\
\hline & & & & {$[0.0094]$} & & {$[0.010]$} \\
\hline $0.775 * * *$ & $0.777 * * *$ & $0.942 * * *$ & $0.969 * * *$ & $0.965^{* * *}$ & $0.982 * * *$ & $0.972^{* * *}$ \\
\hline$[0.018]$ & [0.019] & {$[0.024]$} & {$[0.026]$} & {$[0.026]$} & {$[0.026]$} & {$[0.026]$} \\
\hline 353 & 353 & 345 & 345 & 345 & 345 & 345 \\
\hline 23 & 23 & 23 & 23 & 23 & 23 & 23 \\
\hline
\end{tabular}

Note: Robust standard errors in brackets, ${ }^{* * *} \mathrm{p}<0.01,{ }^{* *} \mathrm{p}<0.05,{ }^{*} \mathrm{p}<0.1$ 
Table 6

Panel Data Instrumental Variables Estimates

Endogenous variables are changes in de facto financial reform and de jure financial reform measures

Standard errors in brackets and clustered at country level, robust to heteroscedasticity

(all RHS variables in first-stage lagged one-period, except political reform)

$$
\text { [1] [2] [3] [4] }
$$

[5] [5]

[6]

[7]

[8]

(endogenous variable is changes in de facto financial reform index)

\begin{tabular}{|c|c|c|c|c|c|c|c|c|}
\hline Financial reform (lag) & $\begin{array}{c}-0.17^{* * *} \\
{[0.057]}\end{array}$ & $\begin{array}{c}-0.145^{* * *} \\
{[0.053]}\end{array}$ & $\begin{array}{c}-0.116^{* *} \\
{[0.046]}\end{array}$ & $\begin{array}{c}-0.179 * * * \\
{[0.055]}\end{array}$ & $\begin{array}{c}-0.178^{* * *} \\
{[0.051]}\end{array}$ & $\begin{array}{c}-0.162 * * * \\
{[0.053]}\end{array}$ & $\begin{array}{c}-0.201^{* * *} \\
{[0.056]}\end{array}$ & $\begin{array}{c}-0.169 * * * \\
{[0.053]}\end{array}$ \\
\hline Political reform & $\begin{array}{c}-0.374 * * \\
{[0.18]}\end{array}$ & $\begin{array}{c}-0.358^{* *} \\
{[0.18]}\end{array}$ & $\begin{array}{c}-0.275^{*} \\
{[0.15]}\end{array}$ & $\begin{array}{c}-0.378^{* *} \\
{[0.19]}\end{array}$ & $\begin{array}{c}-0.351^{* *} \\
{[0.17]}\end{array}$ & $\begin{array}{c}-0.395^{* * *} \\
{[0.15]}\end{array}$ & $\begin{array}{c}-0.25 \\
{[0.16]}\end{array}$ & $\begin{array}{c}-0.337 * \\
{[0.17]}\end{array}$ \\
\hline Political reform squared & $\begin{array}{c}0.313^{* *} \\
{[0.15]}\end{array}$ & $\begin{array}{c}0.332 * \\
{[0.17]}\end{array}$ & $\begin{array}{l}0.201^{*} \\
{[0.12]}\end{array}$ & $\begin{array}{c}0.311^{*} \\
{[0.16]}\end{array}$ & $\begin{array}{c}0.233 \\
{[0.15]}\end{array}$ & $\begin{array}{c}0.341^{* *} \\
{[0.15]}\end{array}$ & $\begin{array}{l}0.102 \\
{[0.13]}\end{array}$ & $\begin{array}{c}0.262 * \\
{[0.14]}\end{array}$ \\
\hline De jure financial reform & $\begin{array}{l}0.0896^{*} \\
{[0.047]}\end{array}$ & $\begin{array}{c}0.0829 * * \\
{[0.038]}\end{array}$ & $\begin{array}{c}0.0973 \\
{[0.081]}\end{array}$ & $\begin{array}{c}0.0625 * * * \\
{[0.024]}\end{array}$ & $\begin{array}{c}0.0699 * * * \\
{[0.023]}\end{array}$ & $\begin{array}{c}0.0623^{* * *} \\
{[0.023]}\end{array}$ & $\begin{array}{c}0.114 * * * \\
{[0.039]}\end{array}$ & $\begin{array}{c}0.0973^{* * *} \\
{[0.038]}\end{array}$ \\
\hline \multicolumn{9}{|c|}{ PANEL B: First-stage regressions } \\
\hline De jure financial reform & $\begin{array}{l}\text { Capital } \\
\text { controls }\end{array}$ & $\begin{array}{l}\text { Interest } \\
\text { rates }\end{array}$ & $\begin{array}{l}\text { Compe- } \\
\text { tition }\end{array}$ & $\begin{array}{l}\text { Supervi- } \\
\text { sion }\end{array}$ & $\begin{array}{l}\text { Privatiza- } \\
\text { tion }\end{array}$ & $\begin{array}{l}\text { Capital } \\
\text { flows }\end{array}$ & Securities & $\begin{array}{l}\text { Fin. Lib } \\
\text { Index }\end{array}$ \\
\hline Financial reform (lag) & $\begin{array}{c}0.111 \\
{[0.152]}\end{array}$ & $\begin{array}{c}-.1442 \\
{[.1664]}\end{array}$ & $\begin{array}{l}-.354 \\
{[.279]}\end{array}$ & $\begin{array}{c}.076 \\
{[.141]}\end{array}$ & $\begin{array}{l}-.049 \\
{[.189]}\end{array}$ & $\begin{array}{c}.082 \\
{[.194]}\end{array}$ & $\begin{array}{l}.288^{*} \\
{[.155]}\end{array}$ & $\begin{array}{c}-.070 \\
{[.0831]}\end{array}$ \\
\hline Political reform & $\begin{array}{c}0.486 \\
{[0.757]}\end{array}$ & $\begin{array}{c}.171 \\
{[1.044]}\end{array}$ & $\begin{array}{c}-1.111 \\
{[1.298]}\end{array}$ & $\begin{array}{c}.293 \\
{[.790]}\end{array}$ & $\begin{array}{c}.064 \\
{[.946]}\end{array}$ & $\begin{array}{c}.1038 \\
{[.9079]}\end{array}$ & $\begin{array}{l}-.648 \\
{[.586]}\end{array}$ & $\begin{array}{l}-.0448 \\
{[.411]}\end{array}$ \\
\hline Political reform squared & $\begin{array}{c}-0.442 \\
{[0.657]}\end{array}$ & $\begin{array}{l}-.655 \\
{[1.07]}\end{array}$ & $\begin{array}{c}1.29 \\
{[1.016]}\end{array}$ & $\begin{array}{l}-.371 \\
{[.845]}\end{array}$ & $\begin{array}{c}.621 \\
{[.838]}\end{array}$ & $\begin{array}{c}-.264 \\
{[.7628]}\end{array}$ & $\begin{array}{l}1.38 * * \\
{[.513]}\end{array}$ & $\begin{array}{c}.096 \\
{[.324]}\end{array}$ \\
\hline Banking crisis & $\begin{array}{c}0.006 \\
{[0.044]}\end{array}$ & $\begin{array}{l}.0397 \\
{[.053]}\end{array}$ & $\begin{array}{c}-.076 \\
{[.0603]}\end{array}$ & $\begin{array}{l}-.084 * * \\
{[.0407]}\end{array}$ & $\begin{array}{l}-.057 \\
{[.068]}\end{array}$ & $\begin{array}{c}.0055 \\
{[.0725]}\end{array}$ & $\begin{array}{l}-.087 \\
{[.059]}\end{array}$ & $\begin{array}{c}-.035 \\
{[.0206]}\end{array}$ \\
\hline Debt crisis & $\begin{array}{c}-0.25^{* * *} \\
{[0.082]}\end{array}$ & $\begin{array}{c}-.224 * * \\
{[.095]}\end{array}$ & $\begin{array}{l}-.158 \\
{[.276]}\end{array}$ & $\begin{array}{c}.0723 \\
{[.1201]}\end{array}$ & $\begin{array}{l}.223 * * * \\
{[.0616]}\end{array}$ & $\begin{array}{c}.095 \\
{[.0609]}\end{array}$ & $\begin{array}{l}.106 * * \\
{[.048]}\end{array}$ & $\begin{array}{l}-.058 \\
{[.097]}\end{array}$ \\
\hline IMF Programme & $\begin{array}{c}-0.003 \\
{[0.021]}\end{array}$ & $\begin{array}{c}.104 * * * \\
{[.032]}\end{array}$ & $\begin{array}{c}-.035 \\
{[.0205]}\end{array}$ & $\begin{array}{c}.0393 \\
{[.0365]}\end{array}$ & $\begin{array}{c}-.007 \\
{[.0359]}\end{array}$ & $\begin{array}{c}-.064 \\
{[.0417]}\end{array}$ & $\begin{array}{c}.002 \\
{[.025]}\end{array}$ & $\begin{array}{c}.019 * \\
{[.0106]}\end{array}$ \\
\hline U.S. interest rates & $\begin{array}{l}-0.015^{*} \\
{[0.008]}\end{array}$ & $\begin{array}{c}.002 \\
{[.0102]}\end{array}$ & $\begin{array}{c}-.027 \\
{[.0168]}\end{array}$ & $\begin{array}{c}-.022 \\
{[.0133]}\end{array}$ & $\begin{array}{c}-.027 \\
{[.0162]}\end{array}$ & $\begin{array}{l}-.025^{*} \\
{[.0116]}\end{array}$ & $\begin{array}{l}-.0005 \\
{[.011]}\end{array}$ & $\begin{array}{c}-.017^{* *} \\
{[.007]}\end{array}$ \\
\hline Recession & $\begin{array}{l}-0.059 * \\
{[0.030]}\end{array}$ & $\begin{array}{c}-.014 \\
{[.0473]}\end{array}$ & $\begin{array}{c}-.002 \\
{[.0519]}\end{array}$ & $\begin{array}{l}-.072 \\
{[.064]}\end{array}$ & $\begin{array}{c}-.197 * * \\
{[.072]}\end{array}$ & $\begin{array}{c}-.069 \\
{[.0638]}\end{array}$ & $\begin{array}{l}-.094 * \\
{[.053]}\end{array}$ & $\begin{array}{c}-.066 * * \\
{[.027]}\end{array}$ \\
\hline High inflation & $\begin{array}{c}-0.042 \\
{[0.035]}\end{array}$ & $\begin{array}{l}-.096 * \\
{[.0501]}\end{array}$ & $\begin{array}{l}-.063 \\
{[.068]}\end{array}$ & $\begin{array}{c}-.131^{* *} \\
{[.057]}\end{array}$ & $\begin{array}{c}-.061 \\
{[.0744]}\end{array}$ & $\begin{array}{c}.008 \\
{[.0601]}\end{array}$ & $\begin{array}{l}.0677 \\
{[.057]}\end{array}$ & $\begin{array}{c}-.081^{* *} \\
{[.033]}\end{array}$ \\
\hline Trade liberalization & $\begin{array}{c}0.329 * * * \\
{[0.082]}\end{array}$ & $\begin{array}{l}.437 * * \\
{[.2007]}\end{array}$ & $\begin{array}{l}.0897 \\
{[.095]}\end{array}$ & $\begin{array}{l}.761 * * * \\
{[.1305]}\end{array}$ & $\begin{array}{c}.649 * * * \\
{[.147]}\end{array}$ & $\begin{array}{l}.797 * * * \\
{[.158]}\end{array}$ & $\begin{array}{c}.454^{* * *} \\
{[.082]}\end{array}$ & $\begin{array}{l}.438 * * * \\
{[.0506]}\end{array}$ \\
\hline Left-wing government & $\begin{array}{c}-0.064 \\
{[0.044]}\end{array}$ & $\begin{array}{l}-.0419 \\
{[.0804]}\end{array}$ & $\begin{array}{c}.0003 \\
{[.0727]}\end{array}$ & $\begin{array}{c}.051 \\
{[.0601]}\end{array}$ & $\begin{array}{c}.0673 \\
{[.0963]}\end{array}$ & $\begin{array}{l}.178^{*} \\
{[.087]}\end{array}$ & $\begin{array}{l}-.037 \\
{[.085]}\end{array}$ & $\begin{array}{l}.0012 \\
{[.032]}\end{array}$ \\
\hline Right-wing government & $\begin{array}{c}-0.085^{* *} \\
{[0.037]}\end{array}$ & $\begin{array}{l}-.076 \\
{[.103]}\end{array}$ & $\begin{array}{c}.009 \\
{[.0647]}\end{array}$ & $\begin{array}{c}-.075 \\
{[.0622]}\end{array}$ & $\begin{array}{c}.0673 \\
{[.0963]}\end{array}$ & $\begin{array}{c}.116^{*} \\
{[.0617]}\end{array}$ & $\begin{array}{c}.072 \\
{[.064]}\end{array}$ & $\begin{array}{l}-.053 \\
{[.035]}\end{array}$ \\
\hline $\begin{array}{l}\text { F test of excluded } \\
\text { instruments }\end{array}$ & $\begin{array}{c}8.240 \\
{[0.0002]}\end{array}$ & $\begin{array}{c}9.06 \\
{[0.0001]}\end{array}$ & $\begin{array}{c}5.17 \\
{[0.002]}\end{array}$ & $\begin{array}{c}16.12 \\
{[0.0000]}\end{array}$ & $\begin{array}{c}32.43 \\
{[0.0000]}\end{array}$ & $\begin{array}{c}39.85 \\
{[0.0000]}\end{array}$ & $\begin{array}{c}12.59 \\
{[0.0000]}\end{array}$ & $\begin{array}{c}38.18 \\
{[0.0000]}\end{array}$ \\
\hline Hansen $J$ statistic & $\begin{array}{c}9.590 \\
{[0.295]}\end{array}$ & $\begin{array}{c}6.993 \\
{[0.537]}\end{array}$ & $\begin{array}{c}7.902 \\
{[0.443]}\end{array}$ & $\begin{array}{c}6.127 \\
{[0.633]}\end{array}$ & $\begin{array}{c}4.619 \\
{[0.797]}\end{array}$ & $\begin{array}{c}5.578 \\
{[0.694]}\end{array}$ & $\begin{array}{c}3.774 \\
{[0.8769]}\end{array}$ & $\begin{array}{c}5.269 \\
{[0.7285]}\end{array}$ \\
\hline Observations & 237 & 237 & 237 & 237 & 237 & 237 & 237 & 237 \\
\hline Number of countries & 16 & 16 & 16 & 16 & 16 & 16 & 16 & 16 \\
\hline
\end{tabular}

Note: Standard errors in brackets, ${ }^{* * *} \mathrm{p}<0.01,{ }^{* *} \mathrm{p}<0.05,{ }^{*} \mathrm{p}<0.1$ 


\section{Appendix. Modelling the non-linearity}

In this appendix we present an extremely simple framework to account for the nonlinear relationship between political regime and financial reform. The model is a simple extension of the Acemoglu and Robinson (2006) workhorse model, which focuses on redistributive politics. One extension of the A-R model is that we assume that in addition to determine tax rates and transfers, the government selects as well the level of financial reform. Financial reform produces efficiency gains but at the same time reduces government revenue per unit of output.

The other extension is given by the presence of heterogeneous elites, associated with different sectors of the economy. Without passing judgement, we assume the economy is composed by two sectors, a "good" sector, "productive”, and a "bad" sector, for instance a sector based on natural resources or traditional technologies. We call capitalists in the "good" sector as the "good" elite and the owners of the firm in the "bad" sector as "bad" elite. Workers form the majority of the population and are employed in both sectors. Population is formed by $N^{b}$, members of the "bad" elite, $N^{g}$, members of the "good" elite, $L^{m}$, workers in productive sector, $L^{o}$, workers in the "bad sector." Total population, $N$, is normalized to be equal to 1.

Output in the productive sector can be produced with two technologies, an advanced and a traditional one. The advanced technology requires a sufficient level of financial development. Thus, output in the productive sector is given by:

$Y^{m}=F\left(K, L^{m}\right) I(Z) \quad$ for $Z \geq Z^{*}$

or

$Y^{m}=L^{m} \quad$ for $Z \leq Z^{*}$

where $Z$ represents the level of development of the financial sector and with 
$I(Z)>1 \quad$ for $Z \geq Z^{*}$.

Workers earn

$w^{m} I(Z) \quad$ for $Z \geq Z^{*}$ or $\quad w^{m}$ for $Z \leq Z^{*}$.

In this specification financial development appears as a public good. The elite and workers in the good sector clearly favour financial development.

In the "bad" sector, output is produced by labour and a natural resource $R$. If labour falls below a given threshold, output cannot be extracted in the sector. Therefore, owners of natural resources have to pay the same wage as in the productive sector. As a result, workers in the natural resource sector benefit as well from financial development. However, financial reform reduces government revenues, and in particular those generated by financial repression. We define such revenue cost as $C(Z)$.

Incomes of the different groups are taxed with the same tax rate $\tau$. Income taxes lead to inefficiencies, measured by a loss function $C(\tau) \bar{y}$, with $C^{\prime}(\tau)>0$, and $\bar{y}$ denoting average income in the economy. The government uses tax revenues to redistribute income through transfers, $T$ in per capita terms, which we assume are the same across groups. In autocracy part of the transfers are directly appropriated by the government ("grabbing hands”).

Given these assumptions, there are three possible equilibria in the model: (i) democracy, with the preference of the workers (the majority of the population) determining policy outcomes; (ii) autocracy, with a political elite in power that wins a political contest against the "bad" elite. The autocratic government is based on consensus from the "good" elite and from the worker-population; (iii) partial or captured democracy, with the "bad" elite dominating the political scene; such regime is unstable as it has no consensus on any parts of the population.

The worker-population prefers high redistribution of income, thus high tax rates, as its income is lower than average income. It also favours financial reform. The "good" elite has a 
preference for low income taxes and it favours financial reform. The "good” elite cannot form a coalition with the "bad" elite as its income crucially rests on the presence of financial development. However, the "good" elite is averse to redistribution and thus has a preference for an autocratic regime that can deliver financial reform and lower taxation. In contrast, democracy will ensure financial reform but will imply high tax rates.

Full democracy and partial democracy are relatively easy to characterize, as they reflect the preference of the worker-population and of the "bad" elite, respectively. The equilibrium in autocracy is more complex, as the government has two objectives: one, is retaining its power, which requires sufficient consensus from the heterogeneous groups; the other, is the appropriation of resources ("grabbing hands”). We will characterize three different political equilibria, related to different reform policies. First, we will define the objective functions of the four players (government, two elites and the worker-population). The indirect utility of the different players are as follows

$V^{b}=(1-\tau) M / N^{b}+T$

for the "bad" elite (with $\mathrm{m}=M / N^{b}$ rents per rentier in the natural resource sector).

$V^{g}=\left[(1-\tau)(1-\alpha) F\left(K, L^{m}\right) I(Z)\right] / N^{g}+T$

for the good elite.

$V^{w}=\left[(1-\tau) \alpha F\left(K, L^{m}\right) I(Z)\left(1+L^{o}\right)\right] /\left(L^{m}+L^{o}\right)+T$

for the worker-population.

Transfers are obtained from the government budget constraint:

$$
T=[\tau-C(Z)-C(\tau)] \bar{y}
$$

The payoff of the autocrat has two components, one related to the "consensus" motive, which involves the utility of the different parts of the population, the other to the appropriation motive of part of tax revenues:

$V^{a}=\mu V^{b}+(1+\mu)\left[V^{g}+V^{w}\right]+\beta T$ 
The two elites and the worker-population have different preferences over $\tau$ and $Z$, derived from the maximization of their utility. The desired tax rate for the "bad" elite is obtained by maximizing the indirect utility with respect to $\tau$. The first order condition is $-m+\left(1-C^{\prime}(\tau)\right) \bar{y}=0$

Under the assumptions that $m>\bar{y}$, and $C^{\prime}(\tau) \leq 1$, the optimal tax rate for the "bad" elite is $\tau=0$, as the LHS is always negative (same result as in Acemoglu and Robinson, 2006a). Furthermore, as financial reform affects negatively the "bad" elite, through the increase in wage costs and through the overall negative effect on budget revenue, the optimal value of $Z$ for the "bad" elite is $Z=0$.

The optimal tax rate for the "good" elite is also zero, again because per capita income of the "good" elite members is higher than the average per capita income. Regarding financial reform, the "good" elite will obviously support it and thus its optimal value of $Z$ is $Z=Z^{*}$. Moreover, the "good" elite does not face a trade-off between income tax rate and financial development, as lack of financial development implies zero income for the "good" elite, irrespective of income taxes.

Finally, we solve for the optimal tax rate and optimal financial reform for the workerpopulation.

The optimal income tax rate desired by the population satisfies:

$\left(\left(\partial V^{w}\right) /(\partial \tau)\right)=0: \quad-w^{m}+\left(1-C^{\prime}(\tau)\right) \bar{y}=0$

Given that $w^{m}<\bar{y}$ then $\tau>0$.

The population desires redistribution, given that its incomes are lower than those of the elites. The optimal choice of development of the financial sector is the same as for the "good" elite, $Z=Z^{*}$. Thus, the worker-population demands redistribution and favours financial development. 
In democracy, the preference of the population will dominate and the outcome will thus be a positive tax rate and financial sector reform. By contrast, under partial democracy, the equilibrium reflects the preferences of one of the elites. We assume that the "bad" elite will prevail because it possesses more resources to be spent in the process of controlling the government. This assumption implies that initially the level of financial development is low, and thus the total amount of profits of the "good" elite are low. Another way to look at the two elites is thinking in terms of incumbents and new entrants. The "resource" sector can be seen as representing the incumbents, while the "manufacturing" sector new entrants.

An additional assumption is that under partial democracy the government is weak and it is not able to counteract the pressure of the elite. In other words, the government is simply a "puppet”, executing the mandate of the "bad" elite, and therefore under partial democracy $Z=0$.

Under autocracy there are equilibria with financial reform. These equilibria arise for two main reasons. One, is the "consensus motive", as the autocrat needs consensus to maintain its power. As the utility of the "good" elite and of the worker-population enters its objective function, the autocrat has incentive to implement financial reform. Second, financial reform may increase the tax base from which the autocrat derives its income (the effect through the appropriation component of the objective function). This effect depends on the net outcome of the increase in manufacturing output and the adverse effect on loss of revenue $(C(Z))$. Therefore, financial reform may help the autocratic government to maintain its power and protect its rent appropriation.

Under autocracy, there are two possible sets of equilibria: one in which the government bases its power on the "bad" elite, the other in which the base for the government power is due to a coalition of the "good" elite and the population. Given our assumptions on the technology in the manufacturing sector, if the government gets support from the "bad 
elite” (thus $\mu=1$ ), $Z=0$ and output in the economy comes solely from the resource sector. Thus, the indirect utility of the government becomes:

$V^{a}=V^{b}+\beta T$

or

$V^{a}=(1-\tau) M / N^{b}+(1+\beta)[\tau-C(\tau)] \bar{y}$

And

$\bar{y}=\left(M / N^{b}\right)\left(N^{b} / N\right)$

Where $N$ is the total population.

The tax rate that maximizes the above indirect utility is obtained from the following condition:

$$
-1+(1+\beta)\left[1-C^{\prime}(\tau)\right]\left(N^{b} / N\right)=0
$$

If $(1+\beta)\left(N^{b} / N\right)<1 \quad$ then $\tau=0$, otherwise $\tau>0$. If the "grabbing hand" objective is high (high $\beta$ ), tax rates can be positive. However, considering that $N^{b}$

is a small proportion of total population, positive tax rates imply that $\beta$ has to approach 1 , an unlikely scenario. In the more likely scenario of zero tax rate, the government does not appropriate any resources, and at the same time faces high risks of loosing power, given the opposition of the large majority of the population.

The second set of equilibria implies financial reform. The "bad" elite opposes such outcome and thus the consensus base is given by the "good" elite and the worker-population. Such situation corresponds to the case in which $\mu=0$.

The objective function of the government is:

$V^{a}=V^{g}+V^{w}+\beta T$

Or

$V^{a}=\left[(1-\tau)(1-\alpha) F\left(K, L^{m}\right) I\left(Z^{*}\right)\right] / N^{e 2}+\left[(1-\tau) \alpha F\left(K, L^{m}\right) I\left(Z^{*}\right)\left(1+L^{o}\right)\right] /\left(L^{m}+L^{o}\right)+$

$(2+\beta)\left[\tau-C\left(Z^{*}\right)-C(\tau)\right] \bar{y}$ 
The condition for the optimal tax rate is:

$$
C^{\prime}(\tau)=1-\left[F\left(K, L^{m}\right) I\left(Z^{*}\right)\left((1-\alpha) / N^{e 2}+\alpha\left(1+L^{o}\right) /\left(L^{m}+L^{o}\right)\right)\right] /[(2+\beta) \bar{y}]
$$

The tax rate is always positive in this case. Thus, the government can appropriate resources and, at the same time, it has a broad support from one elite and the population. Financial reform is a key element for such consensus. If the government cares about consensus, the equilibrium supported by the coalition of the "good" elite and the population dominates.

In sum, the discussion so far has illustrated the fact that financial sector reform decreases during the shift from autocracy to partial democracy, whereas it increases with the shift from partial to full democracy. In summary, the model predicts a non-linear relationship between democracy and financial sector reform.

The outcome in autocracy resembles the result obtained by Goshal and Proto (2008), who model the autocratic regime as one in which the government is supported by a coalition between one elite and the population. 